\title{
Primary production, calcification and macromolecular synthesis in a bloom of the coccolithophore Emiliania huxleyi in the North Sea
}

\author{
Emilio Marañón ${ }^{1, *}$, Natalia González ${ }^{2}$ \\ 'Department of Oceanography, Sauthampton Oceanography Centre, University of Southampton, European Way, \\ Southampton SO14 3ZH, United Kingdom \\ ${ }^{2}$ Unidad de Ecología, Departamento de Biología de Organismos y Sistemas, Universidad de Oviedo, E-33071 Oviedo, Spain
}

\begin{abstract}
Photosynthesis, calcification and the patterns of carbon (C) incorporation into different biomolecules were investigated during a bloom of the coccolithophore Emiliania huxleyi in the North Sea during June and July 1994 . The bloom was confined to an area of ca $3000 \mathrm{~km}^{2}$ centred at $59^{\circ} 50^{\prime} \mathrm{N}$, $00^{\circ} 42^{\prime} \mathrm{E}$ and characterized by enhanced thermal stability and low nitrate concentrations in the upper mixed layer. Surface E. huxleyi densities within the bloom area ranged between 1 and $6 \times 10^{6}$ cells $\mathrm{l}^{-1}$ The mesoscale distribution of $E$. huxleyi abundance suggested that the bloom formation was related to the presence of low concentrations of nitrate rather than phosphate. The bloom was sampled during an. early stage of its development, as indicated by the low calcite- $\mathrm{C}$ levels $\left(<50 \mathrm{mg} \mathrm{C} \mathrm{m}^{-3}\right)$, the low calcite$C$ to particulate organic carbon (POC) ratio $(<0.25)$ and the low density of detached coccoliths $(2$ to $3 \times$ $\left.10^{4} \mathrm{ml}^{1}\right)$. Reduced levels of chlorophyll a $\left(<45 \mathrm{mg} \mathrm{m}^{-2}\right)$ and productivity $\left(<1.2 \mathrm{~g} \mathrm{C} \mathrm{m}^{-2} \mathrm{~d}^{-1}\right)$ were measured in the coccolithophore-rich waters as compared to stations outside the bloom area. Typical calcification rates within the bloom were $135 \mathrm{mg} \mathrm{C} \mathrm{m} \mathrm{m}^{-1}$, representing up to $20 \%$ of the total $\mathrm{C}$ incorporation. Relative $\mathrm{C}$ incorporation into lipids in coccolithophore-rich waters was 1.5 times higher than outside the bloom area. Most of the recently synthesized lipid $(70$ to $90 \%)$ belonged to the neutral lipid fraction. The enhanced lipid synthesis resulted in a higher lipid content of the particulate matter. The relationships between irradiance and photosynthate partitioning consistently showed that $C$ is preferentially channeled into the protein fraction at low light levels, whereas the relative synthesis of lipids increases only at high irradiances. These metabolic responses are discussed in relation to the development of E. huxleyi-rich assemblages. It is concluded that the observed patterns of $C$ incorporation represent a general strategy of energy utilization that is also attributable to other groups of marine phytoplankton.
\end{abstract}

KEY WORDS: Emiliania huxleyj Photosynthesis - Calcification Macromolecular synthesis P-I relationships Lipids

\section{INTRODUCTION}

Coccolithophorids are a group of marine calcifying microalgae, belonging to the class Prymnesiophyceae, that recurrently form extensive $\left(>10^{4} \mathrm{~km}^{2}\right.$ ) blooms in coastal and oceanic regions at temperate and tropical latitudes, annually covering on average $1.4 \times 10^{6} \mathrm{~km}^{2}$ of the world's oceans (Brown \& Yoder 1994). These blooms largely comprise Emiliania huxleyi (Lohman)

\footnotetext{
•E-mail:em1@soc.soton.ac.uk
}

Hay et Moler, which is probably the most important calcite producer in the pelagic environment (Westbroek et al. 1993). In situ measurements have shown that calcification by E. huxleyi, due to its impact on the $\mathrm{CO}_{2}$ chemical equilibria of seawater, may cause a local reduction in the air to sea $\mathrm{pCO}_{2}$ gradient (Robertson et al. 1994), while still representing a carbon sink in the long term through sedimentation of organic and inorganic carbon (Buitenhuis et al. 1996). Furthermore, E. huxleyi is an important producer of the climate-related gaseous compound dimethylsulfide (DMS), whose concentration has been shown to increase by an order 
of magnitude within blooms of this species in the North Atlantic (Matrai \& Keller 1993).

The biogeochemical significance of Emiliania huxleyi is currently fueling intense research into various aspects of its physiology and ecology, including the effects of low salinity on calcification (Paasche et al. 1996), the decoupling between photosynthesis and calcification (Balch et al, 1996), the relationship between irradiance and photosynthesis (Nanninga \& Tyrrell 1996) and the effects of E. huxleyi blooms on zooplankton feeding and reproduction (Nejstgaard et al 1997). In an attempt to relate cellular physiology to the dynamics of bloom formation and its ecological significance, a number of studies have been conducted where the patterns of carbon incorporation into different biomolecules [proteins, polysaccharides, lipids and low molecular weight metabolites (LMWM)] have been determined for culture (Fernández et al. 1994), mesocosm (Marañón et al. 1996) and fjord (Fernández et al. 1996b) populations of E. huxleyi.

These studies showed that Emiliania huxleyi is characterized by a high ( 40 to $50 \%$ ) carbon flow into lipids whereas relative protein synthesis usually accounts for less than $30 \%$ of total organic carbon fixation. It has been suggested that this metabolic strategy would allow the cells to overcome the increase in cellular density associated with coccolith production, therefore extending their residence time in the euphotic layer (Fernández et al. 1994). The high lipid content of $E$. huxleyi populations may have additional trophic implications, given that this species contains unusually high amounts of polyunsaturated fatty acids (Pond \& Harris 1996) which are known to be essential for the growth and reproduction of marine animals including molluscs, crustaceans and fish (Volkman et al. 1980, Sargent et al. 1989). A further consequence of this enhanced lipid synthesis is that E. huxleyi populations would display a remarkably high ( $>12$ by atoms) carbon to nitrogen uptake ratio which in turn would influence the dynamics of the inorganic carbon system in the euphotic layer. However, this metabolic behaviour has only been reported for culture and fjord populations where E. huxleyi represented more than $60 \%$ of total phytoplankton biomass. No information is available on the intracellular flows of photoassimilated carbon and the resulting biochemical composition of particulate matter during offshore E. huxleyi blooms and therefore the wider significance of the observed patterns still needs confirmation.

Recent results from photosynthesis-irradiance experiments with cultures suggest that the lack of photoinhibition at high irradiances may provide a competitive advantage to Emillania huxleyi and help explain why this species tends to bloom when mixed layer depths are shallow and surface irradiances are high
(Nanninga \& Tyrrell 1996). In this regard, it is worth noting that irradiance is a critical factor affecting not only the amount of carbon fixed into organic compounds, but also the biochemical composition of newly synthesized material (Cuhel et al. 1984, Rivkin \& Voytek 1987). Considering that phytoplankton growth rate is often more related to the synthesis of specific compounds rather than to total carbon fixation (Smith \& Morris 1980, Hama et al. 1988), knowledge of the relationship between irradiance and photosynthate partitioning may be useful to ascertain how the strategies of energy utilization by E. huxleyi-rich assemblages affect the dynamics of bloom formation and development.

In comparison with the abundant literature on the physiology of Emiliania huxleyi in cultures, there are relatively few studies where the rates of photosynthesis and calcification have been determined during oceanic blooms (Balch et al. 1992, Fernández et al. 1993, Van der Wal et al. 1995). These measurements were mainly carried out in waters where the bloom was in an advanced stage of development. Remote sensing detection of coccolithophorid blooms is achieved thanks to the increased reflectance of surface waters due to backscattering of light by coccoliths (Holligan et al. 1983, Balch et al. 1991). Given that backscattering depends on coccolith rather than cell concentration (Balch et al. 1991), the detection of these blooms is biased toward their declining stages when the ratio of coccoliths to cells is greatest. Brown \& Yoder (1994) have estimated that satellite-detected coccolithophorid blooms account for less than $1 \%$ of the global annual fluxes of calcite and DMS, suggesting that early stages of bloom development may have greater biogeochemical relevance. From an ecophysiological point of view, a lack of knowledge exists of the patterns of photosynthesis and calcification in actively growing open sea populations of E. huxleyi (Holligan et al. 1993b).

The North Sea is an area where Emiliania huxleyi blooms have been frequently detected (see reviews by Holligan et al. 1989, 1993b) and occasionally sampled (Van der Wal et al. 1995, Buitenhuis et al. 1996) during late spring and summer. During June and July 1994, a cruise was conducted in an area between the Shetland Islands and Norway with the aim of investigating the optical, chemical and biological properties of one of these blooms. Our main objective was to obtain the first account of the patterns of carbon incorporation into different biomolecules and resulting biochemical composition of open sea populations of $E$. huxleyi which were growing actively. This would enable us to assess the wider significance of the previously observed high lipid biosynthesis and to evaluate to which extent this metabolic behaviour may have ecological implications through an increase in the relative 
lipid content of the particulate matter. An additional goal of this study was to establish the relationship between light intensity and photosynthate partitioning in natural E. huxleyi-dominated assemblages, which will aid our understanding of the strategies of energy utilization by phytoplankton and which will lead to empirical equations that relate incident irradiance to the synthesis rate of particular biochemical pools.

\section{METHODS}

The cruise was conducted on board RV 'Hakkon Mosby' from 22 June to 5 July 1994 in an area located between the Shetland Islands and Norway. Before leaving the Norwegian coast, 3 stations were sampled in Hardangerfjorden (SE of Bergen), where a dense bloom of Emiliania huxleyi (surface cell concentrations of up to $12 \times 10^{6}$ cells I$^{-1}$ ) was found. Due to cloudy weather conditions, no satellite images were available before or during the cruise and, therefore, the detection of coccolithophore-rich waters in the North Sea had to rely on discrete E. huxleyi cell counts under the microscope and the continuous on-line monitoring of surface fluorescence and beam attenuation coefficient. After $2 \mathrm{~d}$ of searching, we found an area of low surface transmission centred at $59^{\circ} 47^{\prime} \mathrm{N}, 00^{\circ} 47^{\prime} \mathrm{E}$ where surface E. huxleyi densities reached $7 \times 10^{6}$ cells $1^{-1}$. Photosynthesis and calcification experiments were carried out in a total of 15 stations (12 vertical profiles and 3 surface stations, see Table 1 for details). For the sake of clarity, vertical profiles of standing stock and rate measurements will be presented only for 4 stations: Stns 20 and 24, sampled on 26 and 27 June respectively, were located outside the bloom area, whereas

Table 1. Sampling dates and times and location of the productivity stations visited during the RV 'Hakon Mosby' cruise in June and July 1994

\begin{tabular}{|lcccc|}
\hline Stn & Date (1994) & Time (GMT) & Latitude N & Longitude \\
\hline 02 & 23 Jun & $07: 48$ & $59^{\circ} 56.7^{\prime}$ & $05^{\circ} 45.1^{\prime} \mathrm{E}$ \\
03 & 23 Jun & $12: 25$ & $59^{\circ} 56.3^{\prime}$ & $05^{\circ} 39.3^{\prime} \mathrm{E}$ \\
10 & 25 Jun & $04: 15$ & $60^{\circ} 50.5^{\prime}$ & $00^{\circ} 40.4^{\prime} \mathrm{W}$ \\
12 & 25 Jun & $11: 42$ & $60^{\circ} 50.0^{\prime}$ & $01^{\circ} 00.5^{\prime} \mathrm{E}$ \\
17 & 26 Jun & $05: 35$ & $60^{\circ} 30.3^{\prime}$ & $00^{\circ} 40.4^{\prime} \mathrm{W}$ \\
20 & 26 Jun & $14: 19$ & $60^{\circ} 09.8^{\prime}$ & $01^{\circ} 001^{\prime} \mathrm{E}$ \\
24 & 27 Jun & $06: 23$ & $59^{\circ} 50.2^{\prime}$ & $00^{\circ} 00.1^{\prime} \mathrm{E}$ \\
25 & 27 Jun & $09: 08$ & $59^{\circ} 50.2^{\prime}$ & $00^{\circ} 42.0^{\prime} \mathrm{E}$ \\
26 & 28 Jun & $04: 19$ & $59^{\circ} 49.9^{\prime}$ & $00^{\circ} 42.0^{\prime} \mathrm{E}$ \\
27 & 30 Jun & $02: 26$ & $59^{\circ} 46.7^{\prime}$ & $00^{\circ} 47.2^{\prime} \mathrm{E}$ \\
28 & 30 Jun & $03: 52$ & $59^{\circ} 46.2^{\prime}$ & $00^{\circ} 50.0^{\prime} \mathrm{E}$ \\
30 & 30 Jun & $06: 27$ & $59^{\circ} 46.7^{\prime}$ & $00^{\circ} 50.5^{\prime} \mathrm{E}$ \\
31 & 30 Jun & $07: 56$ & $59^{\circ} 46.9^{\prime}$ & $01^{\circ} 01.9^{\prime} \mathrm{E}$ \\
32 & 1 Jul & $07: 07$ & $59^{\circ} 41.2^{\prime}$ & $00^{\circ} 43.9^{\prime} \mathrm{E}$ \\
45 & 4 Jul & $07: 39$ & $59^{\circ} 25.0^{\prime}$ & $00^{\circ} 53.1^{\prime} \mathrm{E}$ \\
\hline
\end{tabular}

Stns 26 and 32, occupied on 28 June and 1 July, lay within the bloom area (see Fig. 1). Nevertheless, the results from all stations have been included in the data analysis (e.g. Table 2 and Fig. 8).

Optics and hydrography. Surface fluorescence and beam attenuation coefficient at $660 \mathrm{~nm}$ were continuously monitored with a Turner 112 fluorometer and a Seatech $0.25 \mathrm{~m}$ path length transmissometer, respectively, fitted with a pumped seawater supply from an intake depth of 3 to $4 \mathrm{~m}$. Vertical profiles of scalar photosynthetically active radiation (PAR, 400 to $700 \mathrm{~nm}$ ) were obtained with a MER 1032 Multichannel Spectroradiometer (Biospherical Intruments, Inc.). Incident irradiance was continuously measured and recorded throughout the cruise with a $2 \pi$ PAR sensor connected to a LiCor Li-1000 Data Logger. A Seabird CTD system was used to obtain vertical profiles of temperature and salinity. Discrete water samples for chemical and biological analyses were collected from 6 or 7 depths at each station with a rosette of 10 oceanographic Niskin bottles. Nitrate, phosphate and silicate concentrations were determined on fresh samples using a Skalar autoanalyzer and following the methods described in Grasshoff et al. (1983).

Standing stocks. Emiliania huxleyi cell counts were carried out under the microscope on fresh samples using a Fuchs Rosenthal haemocytometer. Chlorophyll a (chl a) concentration was fluorometrically determined after filtration of $250 \mathrm{ml}$ samples through GF/F Whatman filters and extraction in $90 \%$ acetone overnight. Extracts were read on a 10-AU Turner Designs Fluorometer previously calibrated with pure chI a (Sigma). Identification and counting of the microplankton species were carried out under an inverted microscope at the end of the cruise, using samples preserved both in Lugol's iodine and buffered formalin. Cell numbers were transformed into estimated carbon biomass as in Holligan et al. (1984).

For the analysis of total particulate carbon (TPC) and carbon present as calcium carbonate (calcite-C), duplicate 0.5 to $1.0 \mathrm{l}$ samples were filtered through $\mathrm{GF} / \mathrm{F}$ Whatman filters which were subsequently stored frozen at $-20^{\circ} \mathrm{C}$. TPC was determined with a CarloErba 1500 series $2 \mathrm{CHN}$ analyzer without any treatment to remove carbonates. Calcite-C was estimated from the calcium content determined by flame atomic absorption spectrometry, assuming all the particulate calcium was in the form of calcium carbonate. Prior to analysis, samples for calcite were acidified with $2 \mathrm{ml}$ $50 \% \mathrm{HCl}$, extracted at $40^{\circ} \mathrm{C}$ for $12 \mathrm{~h}$ and diluted with $8 \mathrm{ml} \mathrm{1 \%}$ lanthanum chloride. Particulate organic carbon (POC) was calculated as the difference between TPC and calcite-C. For determination of the biochemical composition of seston, duplicate $0.5 \mathrm{l}$ samples were filtered through pre-combusted GF/F Whatman filters 
and stored at $-20^{\circ} \mathrm{C}$ until further analysis. The concentration of particulate lipid was determined spectrophotometrically following the method of Barnes \& Blackstock (1973). The carbon content of the lipid pool was assumed to be $84 \%$ (Fraga \& Pérez 1990).

Photosynthesis and calcification. Vertical profiles of the rates of photosynthesis and calcification were determined using simulated in situ incubations with the radioisotope ${ }^{14} \mathrm{C}$. Duplicate acid-washed $70 \mathrm{ml}$ polycarbonate bottles were filled with the seawater sample, spiked with $370 \mathrm{kBq}(10 \mu \mathrm{Ci}) \mathrm{NaH}^{14} \mathrm{CO}_{3}$ and placed in an on-deck incubator refrigerated by circulating surface seawater The incubator was equipped with a set of neutral density screens that provided a range of 7 irradiances from 100 to $1 \%$ of incident irradiance $\left(I_{0}\right)$. Each sample was incubated at a light level as close as possible to the irradiance measured at its depth of origin, taking into account the PAR profile obtained at the station. The experiments started between 07:00 and 08:30 h and lasted for $24 \mathrm{~h}$. At the end of the incubations, samples were filtered under low vacuum pressure ( $<100 \mathrm{~mm} \mathrm{Hg}$ ) onto GF/F Whatman filters which were immediately frozen at $-20^{\circ} \mathrm{C}$ until subsequent analysis in the laboratory. The amount of ${ }^{14} \mathrm{C}$ incorporated into the main end-products of photosynthesis was determined using the biochemical fractionation procedure detailed in Marañón et al. (1995). This technique allows partitioning of the newly synthesized material into 4 fractions: proteins, polysaccharides, lipids and low molecular weight metabolites.

At particular stations, lipid carbon was partitioned into 3 classes (neutral lipid, polar lipids and phospholipids) by using silica gel chromatography (Smith \& D'Souza 1993) as explained in Fernández et al. (1994). Radioactivity on each fraction was measured on a Packard 2500 liquid scintillation counter. Quenching was corrected by the channels ratio method. Total carbon fixation was calculated as the sum of the 4 fractions. In preliminary experiments, no significant differences were found between total carbon incorporation in non-fractionated samples and the sum of the carbon incorporated into the 4 fractions ( $t$-test, $p>0.3$ ).

Calcification experiments were run in parallel with the photosynthesis experiments. Inoculation, incubation, filtration and storage of the samples were carried out as indicated above for the photosynthesis experiments, except that 3 replicates were used instead of 2 . Once in the laboratory, calcification rates were determined following the microdiffusion procedure described by Paasche \& Brubak (1994). This technique does not involve splitting of the sample into 2 fractions and calculating the inorganic carbon fixation as the difference in radioactivity between an untreated and an acid-fumed filter. As a result, the microdiffusion procedure is quicker and more reliable than the widely used 'splitting' technique and allows more precise measurements of the rate of carbon incorporation into coccoliths

At selected stations, we conducted additional experiments in order to determine the relationship between irradiance and the carbon incorporation into each biochemical pool. These photosynthesis-irradiance $(P-I)$ experiments were conducted in an on-deck incubator that provided the following range of irradiances: 100 , $58,40,20,8,2$ and $0 \%$ of $I_{0}$. Sampling, inoculation, filtration and subsequent storage and analysis of the samples were completed as previously described. The experiments were done between 10:00 and 21:00 h and lasted for 9 to $10 \mathrm{~h}$. The duration of the experiments was therefore long enough to ensure that isotopic equilibrium between each pool and its precursors was accomplished (Li \& Harrison 1982). For each biochemical fraction, individual replicate measurements were fitted to the continuous exponential model by Platt et al. (1980) using non-linear least squares regression:

$$
P^{\mathrm{B}}=P_{\mathrm{s}}\left[1-\exp \left(-\alpha I / P_{\mathrm{s}}\right)\right]\left[\exp \left(-\beta I / P_{\mathrm{s}}\right)\right]
$$

where $P^{B}$ (mg C mg chl ${ }^{-1} \mathrm{~h}^{-1}$ ) is the chlorophyll-normalized rate of carbon incorporation; $P_{\mathrm{s}}\left(\mathrm{mg} \mathrm{C} \mathrm{mg} \mathrm{chl}^{-1}\right.$ $\mathrm{h}^{-1}$ ) is the maximum rate of chlorophyll-normalized carbon incorporation without photoinhibition; $\alpha$ [mg C $\left.m g \mathrm{chl}^{-1} \mathrm{~h}^{-1}\left(\mu E \mathrm{~m}^{-2} \mathrm{~s}^{-1}\right)^{-1}\right)$ is the initial slope of the $P_{-1}$

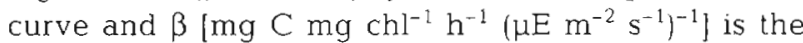
photoinhibition parameter. Statistical fitting of the curves was performed using SPSS v6.1.2 software. The realized maximum rate of carbon incorporation $\left(P^{\mathrm{B}}{ }_{\mathrm{m}}\right.$ $\mathrm{mg} \mathrm{C} \mathrm{mg} \mathrm{chl}^{-1} \mathrm{~h}^{-1}$ ) was then calculated as

$$
P_{\mathrm{m}}^{\mathrm{B}}=P_{\mathrm{s}}[\alpha /(\alpha+\beta)][\beta /(\alpha+\beta)]^{\beta / \alpha}
$$

In those experiments where $\beta$ was not significantly different from zero, we compared the values of the photosynthetic parameters obtained using the continuous exponential model with those obtained using the hyperbolic tangent model, which does not include a photoinhibition parameter. Both models gave parameter estimates that differed in less than $10 \%$ of the mean. Differences between estimates from each model were not significant (paired $t$-test, $p>0.05$ ).

\section{RESULTS}

\section{Hydrography and bloom distribution}

Hydrographical data indicate that a typical summer situation was present in the Shetland continental shelf at the time of the cruise. Salinity was relatively homogeneous in both the vertical and the horizontal scale, showing variations of less than 0.1 psu. The vertical distribution of density was controlled by temperature, 

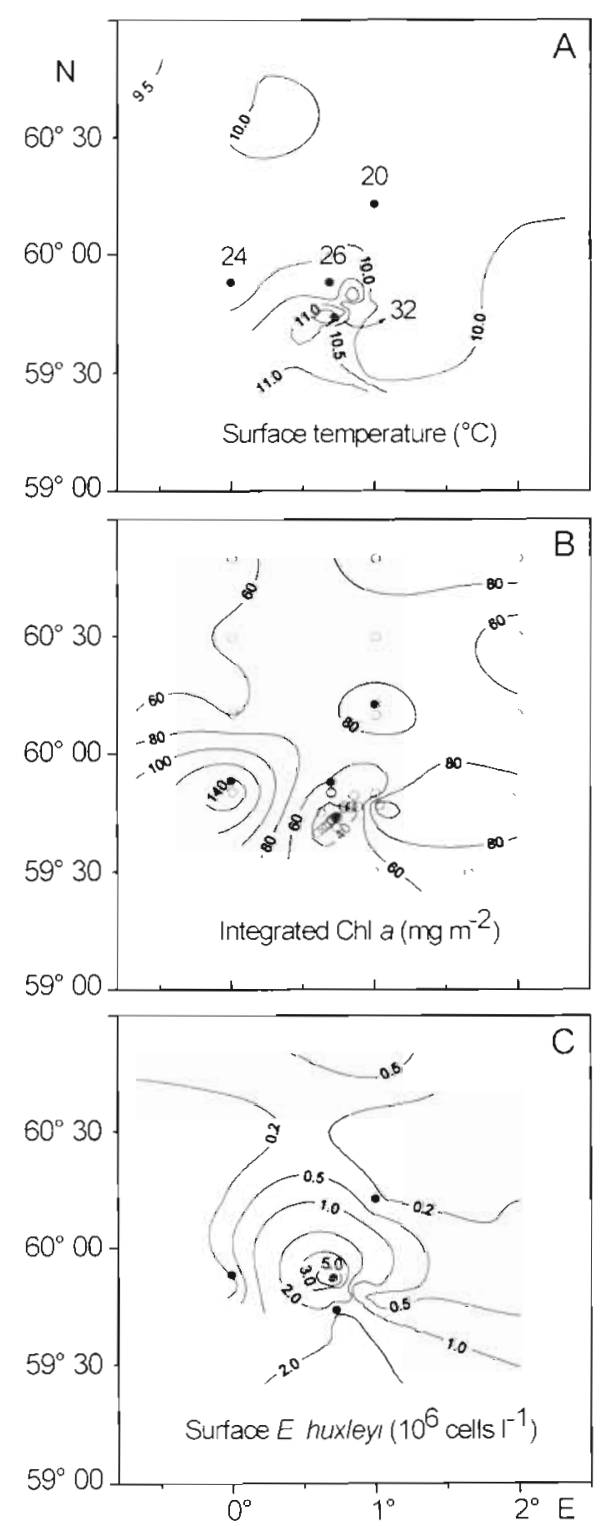

Fig. 1. Spatial distribution of (A) surface temperature, (B) integrated chlorophyll a concentration and (C) surface Emiliania huxleyi concentration in the North Sea from 24 June to 4 July 1994. (O in B) Position of all the stations sampled in the area. (-) Position of the 4 representative stations. Stns 20 and 24 were located outside the bloom area whereas Stns 26 and 32 lay within the bloom area.

as shown by the close agreement between isopycnals and isotherms. A well-developed thermocline was present at 30 to $60 \mathrm{~m}$ throughout the cruise area, except at 2 stations located along $00^{\circ} 40^{\prime} \mathrm{W}$ near the coasts of Shetland, where mixing extended through the whole water column. Surface temperature ranged between 9.5 and $11^{\circ} \mathrm{C}$ (Fig. $1 \mathrm{~A}$ ). Towards the end of the cruise, an increase in surface temperature (of up to $1.5^{\circ} \mathrm{C}$ ) was detected in coccolithophore-rich waters.
This increase affected only the upper 5 to $10 \mathrm{~m}$ of the water column and was not paralleled by any change in salinity distribution, suggesting enhanced solar heating took place during that period. No information is available on the temperature distribution in nonbloom waters during the late phase of the cruise However, the magnitude of the observed heating of coccolithophore-rich waters (up to $1.5^{\circ} \mathrm{C}$ ) was too large to have been caused by increased light scattering by coccoliths, as has been reported in other studies (Robertson et al. 1994). Therefore, it is likely that a similar temperature increase also took place outside the bloom area.

The bloom of Emiliania huxleyi (surface densities above $1 \times 10^{6}$ cells $\mathrm{l}^{-1}$ ) was confined to a small area of about $3000 \mathrm{~km}^{2}$ located between $60^{\circ} 10^{\prime} \mathrm{N}, 0^{\circ} 00^{\prime} \mathrm{W}$ and $59^{\circ} 40^{\prime} \mathrm{N}, 1^{\circ} 00^{\prime} \mathrm{E}$ (Fig. 1C). Maximum surface densities were $6 \times 10^{6}$ cells $\mathrm{I}^{-1}$. A positive correlation can be observed in Fig. 1 between surface temperature and $E$. huxleyi density, which is explained by the fact that sampling of the bloom was concentrated towards the late phase of the cruise when an increase in solar heating was taking place. In the southern part of the cruise area, the distribution of E. huxleyi abundance followed an opposite pattern to that of chl a concentration (Fig. 1B, C). Integrated chl a concentration in the bloom area was usually below $80 \mathrm{mg} \mathrm{m}^{-2}$, whereas highest chl a concentrations ( $>100 \mathrm{mg} \mathrm{m}^{-2}$ ) were measured outside the bloom area.

The position of the 4 representative stations is indicated on Fig. 1. The 4 stations were located in a relatively small area and were sampled within a time interval of $4 d$, therefore showing a similar hydrographic structure (Fig. 2). Temperature in the upper mixed layer ranged between 9.6 and $10.3^{\circ} \mathrm{C}$ at all the 4 stations and surface waters were warmer at the bloom stations (Fig. 2A). The upper mixed layer extended down to $40 \mathrm{~m}$ at the 4 stations, but the thermocline and hence the pycnocline were steeper at the bloom stations. Stns 20 and 24 showed higher salinity (ca 35.20 psu) in the upper mixed layer as compared to the stations within the bloom area (ca 35.13) (Fig 2B). Upper mixed layer density was lower at Stns 26 and 32 , which displayed a larger difference in density between the surface and the bottom layer (Fig. 2C). In summary, we can conclude that thermal stratification was stronger at the bloom stations and mixing within the upper layer more intense outside the bloom area. This trend is supported by the observation that the average density difference between surface and $60 \mathrm{~m}$ was significantly higher at the bloom stations (Table 2).

Except for a higher concentration of nitrate and phosphate in the upper mixed layer at Stn 20 , the vertical distribution of nutrients was similar at the 4 stations (Fig. 3). Nitrate was depleted in surface waters at 

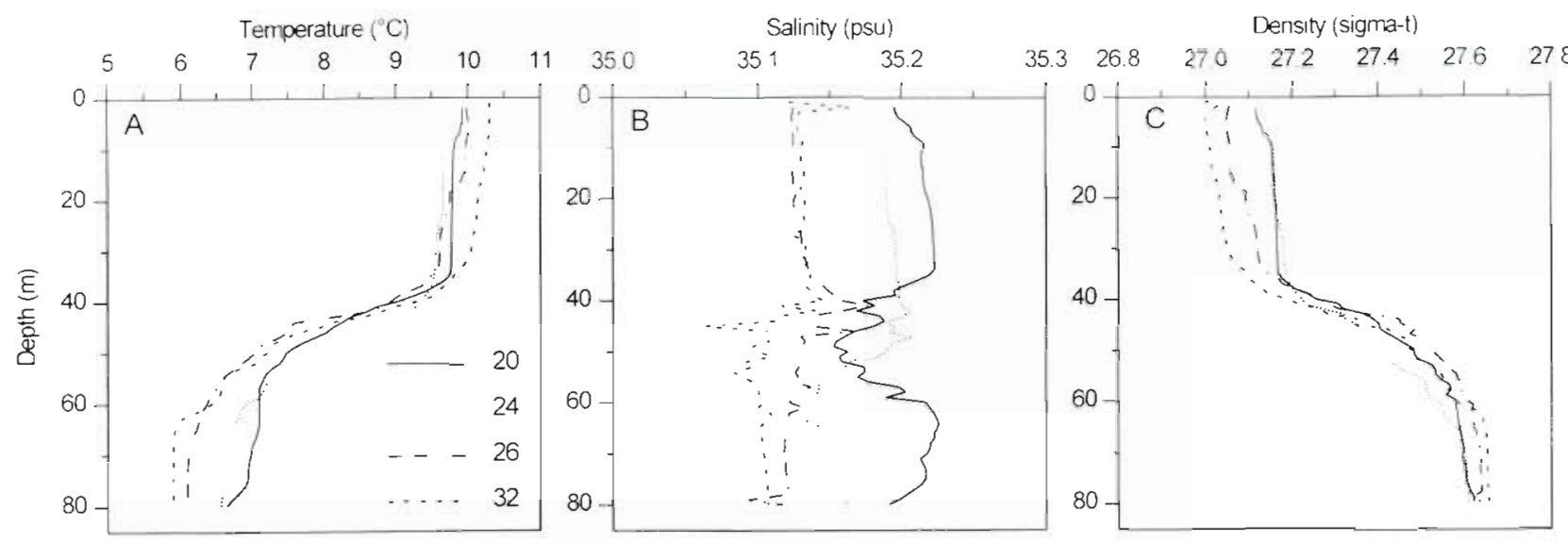

Fig. 2. Vertical profiles of (A) temperature, (B) salinity and (C) density at Sins 20,24, 26 and 32
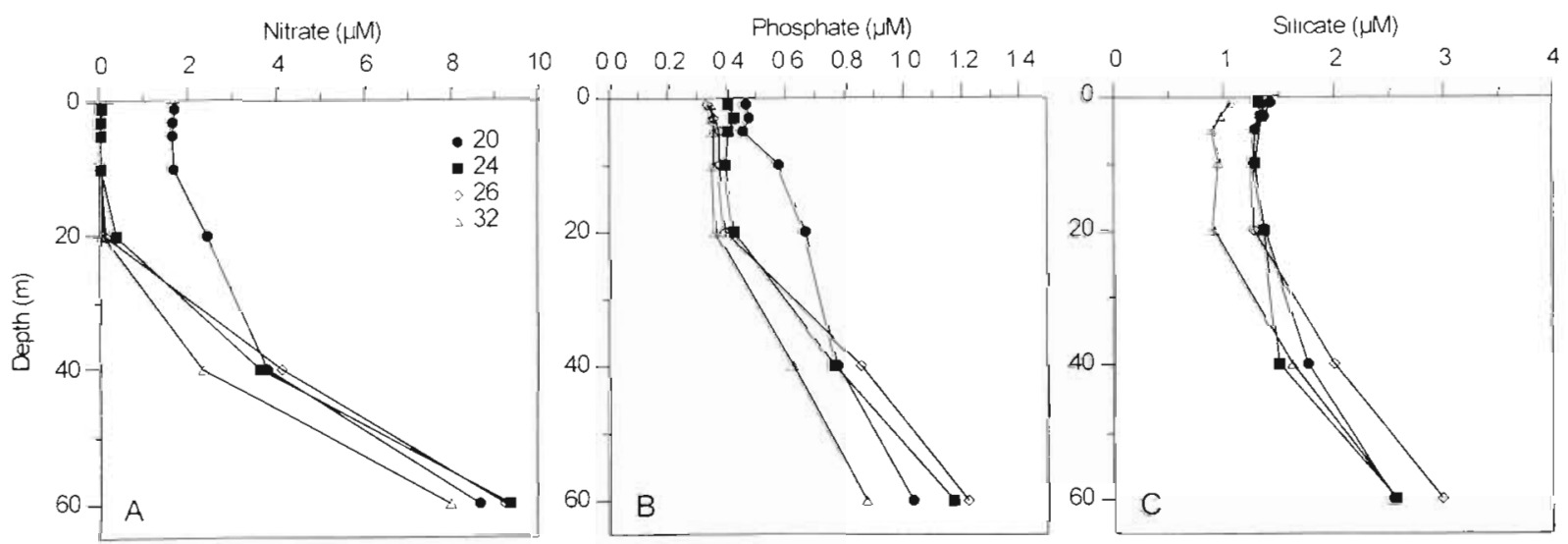

Fig. 3. Vertical profiles of (A) nitrate, (B) phosphate and (C) silicate concentration at Stns 20,24, 26 and 32

Table 2. Average values for selected physical, chemical and biological variables at 12 productivity stations located outside and within the Emiliania huxleyi bloom area in the North Sea during June and July 1994 . Standing stocks and rates were integrated in the upper $40 \mathrm{~m}$, except for calcification and the calcification to photosynthesis ratio, which where integrated in the upper $20 \mathrm{~m}$. Statistical significance of the differences between bloom and nonbloom stations was assessed by using the Kruskal-Wallis (K-W) test ( $" p \leq 0.05 ;$ ns: not significant). POC: particulate organic carbon

\begin{tabular}{|c|c|c|c|c|c|}
\hline \multirow[t]{2}{*}{ Variable } & \multicolumn{2}{|c|}{ Nonbloom } & \multicolumn{2}{|c|}{ Bloom } & \multirow[t]{2}{*}{$\mathrm{K}$-W test } \\
\hline & Mean & $\mathrm{SE}$ & Mean & $\mathrm{SE}$ & \\
\hline Density difference $0-60 \mathrm{~m}$ & 0.20 & 0.09 & 0.60 & 0.06 & $\cdot$ \\
\hline Upper mixed layer temperature $\left({ }^{\circ} \mathrm{C}\right)$ & 9.59 & 0.1 .1 & 9.98 & 0.17 & ns \\
\hline Euphotic layer nitrate $(\mu \mathrm{M})$ & 2.30 & 0.62 & 0.01 & 0.00 & $\cdot$ \\
\hline Euphotic layer phosphate $(\mu M)$ & 0.54 & 0.05 & 0.36 & 0.01 & $\cdot$ \\
\hline Euphotic layer silicate $(\mu M)$ & 1.45 & 0.13 & 0.93 & 0.15 & • \\
\hline Surface E. huxleyi $\left(10^{6}\right.$ cells $\left.\mathrm{l}^{-1}\right)$ & 0.31 & 0.12 & 3.7 & 1.0 & $\cdot$ \\
\hline 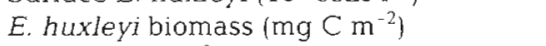 & 37.5 & 18.6 & 1214.9 & 289.6 & $\cdot$ \\
\hline $\mathrm{POC}\left(\mathrm{mg} \mathrm{C} \mathrm{m} \mathrm{m}^{-2}\right)$ & 8320.3 & 275.8 & 7703.0 & 833.5 & ns \\
\hline Calcite-C (mg C m-2) & 230.7 & 88.2 & 1554.5 & 558.3 & $\cdot$ \\
\hline Chlorophyll a $\left(\mathrm{mg} \mathrm{m}^{-2}\right)$ & 100.7 & 21.4 & 43.2 & 3.9 & $\cdot$ \\
\hline Photosynthesis ( $\mathrm{mg} \mathrm{C} \mathrm{m} \mathrm{Cl}^{-2} \mathrm{~d}^{-1}$ ) & 3209.9 & 1260.6 & 1100.1 & 108.0 & ns \\
\hline Photosynthesis/chl a (mg C mg chl ${ }^{-1} \mathrm{~d}^{-1}$ ) & 28.5 & 6.2 & 25.4 & 4.8 & ns \\
\hline Calcification ( $\mathrm{mg} \mathrm{C} \mathrm{m} \mathrm{C}^{-2} \mathrm{~d}^{-1}$ ) & 42.6 & 5.6 & 135.2 & 48.5 & $\cdot$ \\
\hline Calcification/photosynthesis & 0.02 & 0.01 & 0.16 & 0.1 & $\cdot$ \\
\hline
\end{tabular}


Fig. 4. Vertical profiles of the concentration of (A) chlorophyll $a$, (B) particulate organic carbon (POC) and (C) calcite-C and (D) the abundance of Emiliania huxleyi at Stns 20,24, 26 and 32
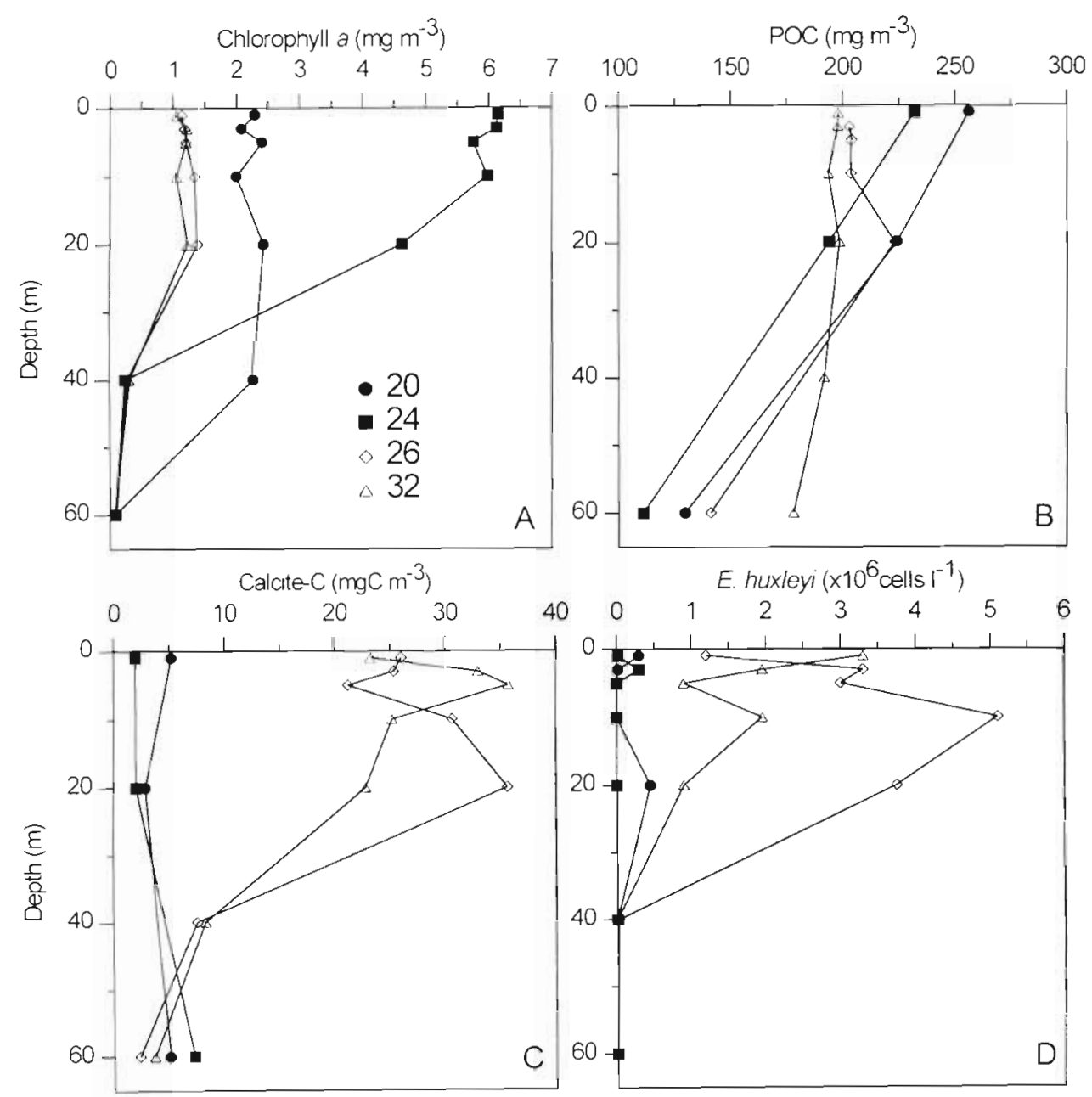

40

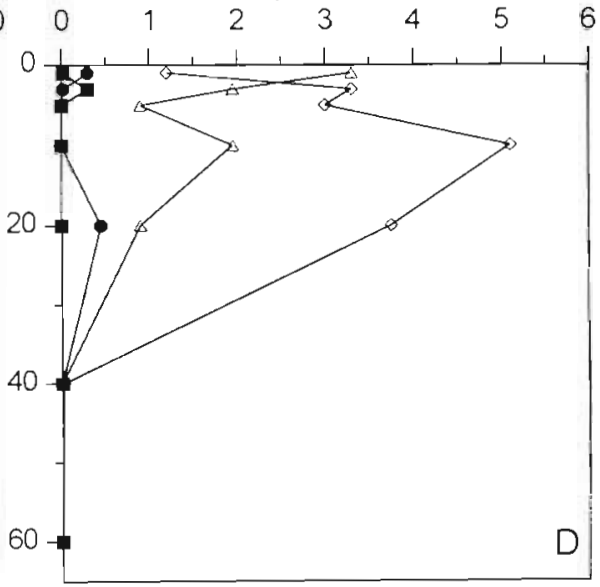

Stns 24, 26 and 32, whereas measurable amounts of phosphate $(>0.3 \mu \mathrm{M})$ and silicate $(>0.9 \mu \mathrm{M})$ were always present in the upper mixed layer. In all stations, nutrient concentration increased dramatically below the thermocline. Overall, nutrient concentrations in the euphotic layer (above the $1 \%$ isolume) were significantly higher at the stations outside the bloom area (Table 2). This was particularly true for nitrate, which was undetectable in most of the bloom stations but showed a concentration of $2.30 \pm 0.62 \mu \mathrm{M}$ in coccolithophore-poor waters.

\section{Standing stocks and phytoplankton composition}

Chl a concentration was significantly higher in the stations outside the bloom area (Table 2, Figs. 1B \& $4 \mathrm{~A})$. Values of about $1 \mathrm{mg} \mathrm{m}^{-3}$ were measured in the upper mixed layer at Stns 26 and 32, whereas concentrations as high as 2.4 and $6.1 \mathrm{mg} \mathrm{m}^{-3}$ were recorded in surface and subsurface waters at Stns 20 and 24, respectively. Considering all the productivity stations, integrated chl a concentration outside the bloom area $\left(100.7 \pm 21.4 \mathrm{mg} \mathrm{m}^{-2}\right)$ was significantly higher than that measured in the coccolithophore-rich waters $(43.2 \pm$ $3.9 \mathrm{mg} \mathrm{m}^{-2}$ ) (Table 2). Paralleling the distribution of chl a concentration, highest levels of POC $>225 \mathrm{mg} \mathrm{C}$ $\mathrm{m}^{-3}$ ) were measured in surface coccolithophore-poor waters (Fig. 4B). Except at Stn 32, which showed an homogeneous vertical profile, a decrease in POC concentration was always detected below the thermocline. Outside the bloom area, calcite-C concentration was below $8 \mathrm{mg} \mathrm{C} \mathrm{m}^{-3}$ throughout the water column (Fig. 4C). Typical calcite-C concentrations of above $20 \mathrm{mg} \mathrm{C} \mathrm{m}^{-3}$ were measured in the top $20 \mathrm{~m}$ in the coccolithophore-rich waters. The highest calcite- $C$ concentrations ( $>80 \mathrm{mg} \mathrm{C} \mathrm{m}^{-3}$ ) were recorded during the last sampling day at 2 stations where the Emiliania huxleyi bloom had probably lasted for a longer time.

Emiliania huxleyi densities outside the bloom area were always below $0.5 \times 10^{6}$ cells $^{-1}$ (Table 2, Fig. 4D) Maximum E. huxleyi concentrations were measured at 

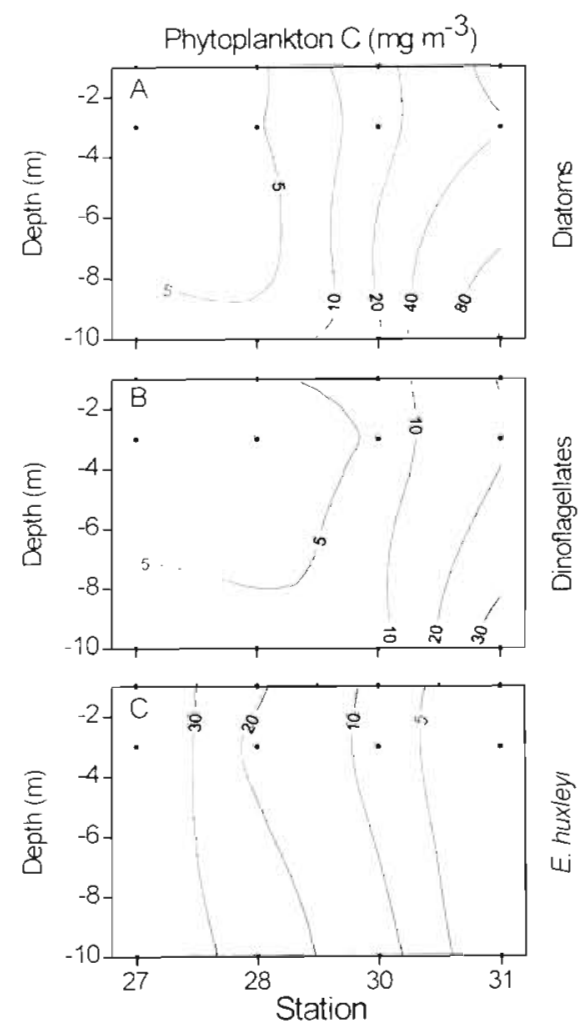

Fig. 5. Estimated (A) diatom, (B) dinoflagellate and (C) Emiliania huxleyi carbon biomass along a transect running west to east from the core of the bloom area $\left(\operatorname{Sin} 27,59^{\circ} 47^{\prime} \mathrm{N}\right.$, $00^{\circ} 47^{\prime} \mathrm{E}$ ) to the outer margin of the bloom area (Stn 31, $59^{\circ} 47^{\prime} \mathrm{N}, 01^{\circ} 02^{\prime} \mathrm{E}$ ) on 30 June 1994

the surface at Stn $32\left(3.3 \times 10^{6}\right.$ cells $\left.^{-1}\right)$ and at $10 \mathrm{~m}$ at

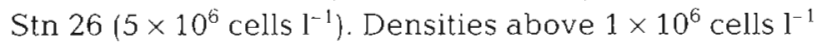
were found at both stations throughout the upper $20 \mathrm{~m}$ of the water column. No information is available on the density of free coccoliths at these stations. However, this density was determined at Stns 25 and 27, which were located in the bloom area within a distance of less than 8 nautical miles. At these stations, the subsurface concentration of detached coccoliths ranged between 24000 and 50000 liths $\mathrm{ml}^{-1}$, and the ratio of free coccoliths to living $E$. huxleyi cells varied between $\vec{F}$ and 34 coccoliths cell ${ }^{-1}$.

The taxonomic composition of the phytoplankton assemblages was determined for a transect running west to east from the centre of the coccolithophore-rich area to the outer margin of the bloom area along $59^{\circ} 47^{\prime} \mathrm{N}$ (Fig. 5). Low levels of diatom and dinoflagellate biomass ( $<5 \mathrm{mg} \mathrm{C} \mathrm{m}{ }^{-3}$ ) were measured in the centre of the bloom, where Emiliania huxleyi biomass was between 35 and $40 \mathrm{mg} \mathrm{C} \mathrm{m}^{-3}$. It is difficult to assess the E. huxleyi contribution to the total phytoplankton biomass, mainly because of the uncertain abundance of small flagellates. It is likely that these small flagellates represented an important contribution to the total phytoplankton biomass, given that 40 to $50 \%$ of the total chl $a$ in the coccolithophore-rich waters was measured in the $<5 \mu \mathrm{m}$ size fraction (Evy Skjoldal pers. comm.). The ratio of $E$. huxleyi organic carbon biomass to POC typically was in the range 0.1 to 0.2 within the bloom area. Towards the eastern end of the transect, the abundance of diatoms and dinoflagellates increased up to 80 and $30 \mathrm{mg} \mathrm{C} \mathrm{m}^{-3}$, respectively, paralleling the decrease in E. huxleyi density and an increase in chl a concentration.

\section{Photosynthesis and calcification}

The vertical distribution of photosynthesis rate mirrored that of chl a concentration both inside and outside the bloom area (Fig. 6A). Photosynthesis rates outside the bloom area exceeded those measured within the coccolithophore-rich waters (Fig. 6A, Table 2). Highest rates of carbon fixation were always measured in surface waters. Photosynthesis rate in the coccolithophore-rich waters was always lower than $80 \mathrm{mg} \mathrm{C}$ $\mathrm{m}^{-3} \mathrm{~d}^{-1}$, giving an integrated carbon production of 1028.0 and $1312.5 \mathrm{mg} \mathrm{C} \mathrm{m}^{-2} \mathrm{~d}^{-1}$ at Stns 26 and 32. respectively. In contrast, surface photosynthesis rates of 250 and $540 \mathrm{mg} \mathrm{C} \mathrm{m}^{-3} \mathrm{~d}^{-1}$ were measured, respectively, at Stns 20 and 24 . Integrated carbon fixation rates at these stations were 3283.5 and $6693.0 \mathrm{mg} \mathrm{C}$ $\mathrm{m}^{-2} \mathrm{~d}^{-1}$. The higher production rates measured at the non-bloom stations were related not only to a larger phytoplankton biomass, but also to an enhanced photosynthetic yield of chl $a$. The photosynthesis to chl a ratio in surface waters was significantiy higher at the non bloom stations (20 and 24 ), reaching values of 88 and $108 \mathrm{mg} \mathrm{C} \mathrm{mg} \mathrm{chl} \mathrm{m}^{-1} \mathrm{~d}^{-1}$, respectively (Fig. 6B). Considering all the stations sampled during the cruise, however, the average integrated photosynthesis to chl a ratio in coccolithophore-rich waters $(25.4 \pm 4.8)$ was only slightly lower than that measured outside the bloom area $(28.5 \pm 6.2)$ (Table 2 ).

Calcification rates below $5 \mathrm{mg} \mathrm{C} \mathrm{m}^{-3} \mathrm{~d}^{-1}$ were medsured at Stns 20,24 and 32 (Fig. 6C). By contrast, calcification was relatively high at $\operatorname{Stn} 26$, where we measured rates as high as $15.9 \mathrm{mg} \mathrm{C} \mathrm{m}^{-3} \mathrm{~d}^{-1}$ The quantitative significance of inorganic carbon fixation is better understood when compared to the organic carbon production. At the stations outside the bloom area, the calcification to photosynthesis ratio was in all samples lower than 0.03. At Stn 26, the calcification to photosynthesis ratio was between 0.25 and 0.43 , whereas at Stn 32 this ratio ranged between 0.05 and 0.1 in the upper $20 \mathrm{~m}$. At both stations, the calcification to photosynthesis ratio was higher in subsurface waters. Inorganic carbon production averaged $135.2 \pm 48.5 \mathrm{mg} \mathrm{C}$ 
Fig. 6. Vertical profiles of (A) photosynthesis rate, (B) photosynthesis to chlorophyll a ratio, (C) calcification and (D) calcification to photosynthesis ratio at Stns 20,24, 26 and 32 . Bars represent \pm 1 standard error (SE)

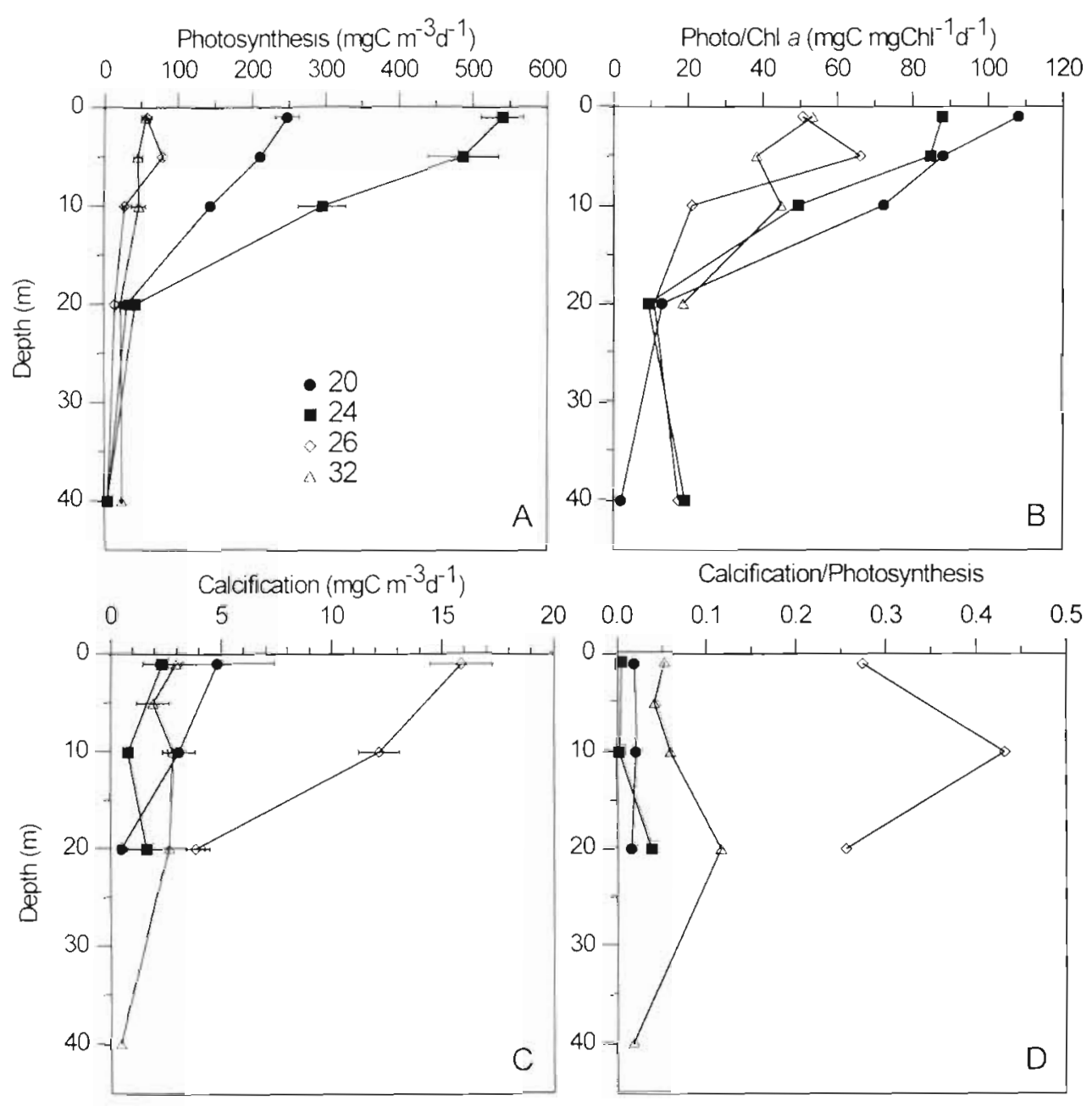

$\mathrm{m}^{-3} \mathrm{~d}^{-1}$ at the bloom stations, giving a mean calcification to photosynthesis ratio for coccolithophore-rich waters of $0.16 \pm 0.1$ (Table 2 )

\section{Carbon incorporation into biochemical pools}

The vertical distribution of relative carbon $(\mathrm{C})$ incorporation into each biochemical fraction in the 4 stations is shown in Fig. 7. Proteins were quantitatively the most important fraction, in general constituting more than $40 \%$ of newly photosynthesized C (Fig. 7A). At the stations outside the bloom area, relative $\mathrm{C}$ incorporation into proteins was vertically homogeneous, with values in the range 40 to $50 \%$. In contrast, an increase in the $\mathrm{C}$ flow into this fraction was measured in subsurface waters at the coccolithophore-rich stations. This increase was particularly dramatic at Stn 32, where up to $74.4 \%$ of incorporated $C$ was channeled into the protein fraction at $40 \mathrm{~m}$. Relative polysaccharide synthesis ranged between 20 and $25 \%$ at surface waters within the bloom area and more than $30 \%$ at Stn 24 (Fig. 7B). Except at Stn 20, where relative C incorporation into polysaccharides increased slightly with depth, this variable tended to decrease at subsurface waters. Carbon channeled into the LMWM fraction accounted for 10 to $30 \%$ of total C incorporation in surface waters (Fig. 7D) and, excluding Stn 20, showed an increasing trend with depth. No clear differences were found between the stations located in the coccolithophore-rich waters and those located outside the bloom area.

The relative incorporation of $\mathrm{C}$ into lipids was lower than 20\% throughout the cruise (Fig. 7C). At the stations outside the bloom area, no clear pattern of vertical distribution was noticeable and percentages of $\mathrm{C}$ incorporation were always below $13 \%$. In contrast, the relative synthesis of lipids in the coccolithophore-rich stations showed a 2 -fold increase from values below $8 \%$ at the bottom of the upper mixed layer to values above $15 \%$ in surface waters. Fig. $8 \mathrm{~A}$ shows the vertical distribution of the relative lipid 


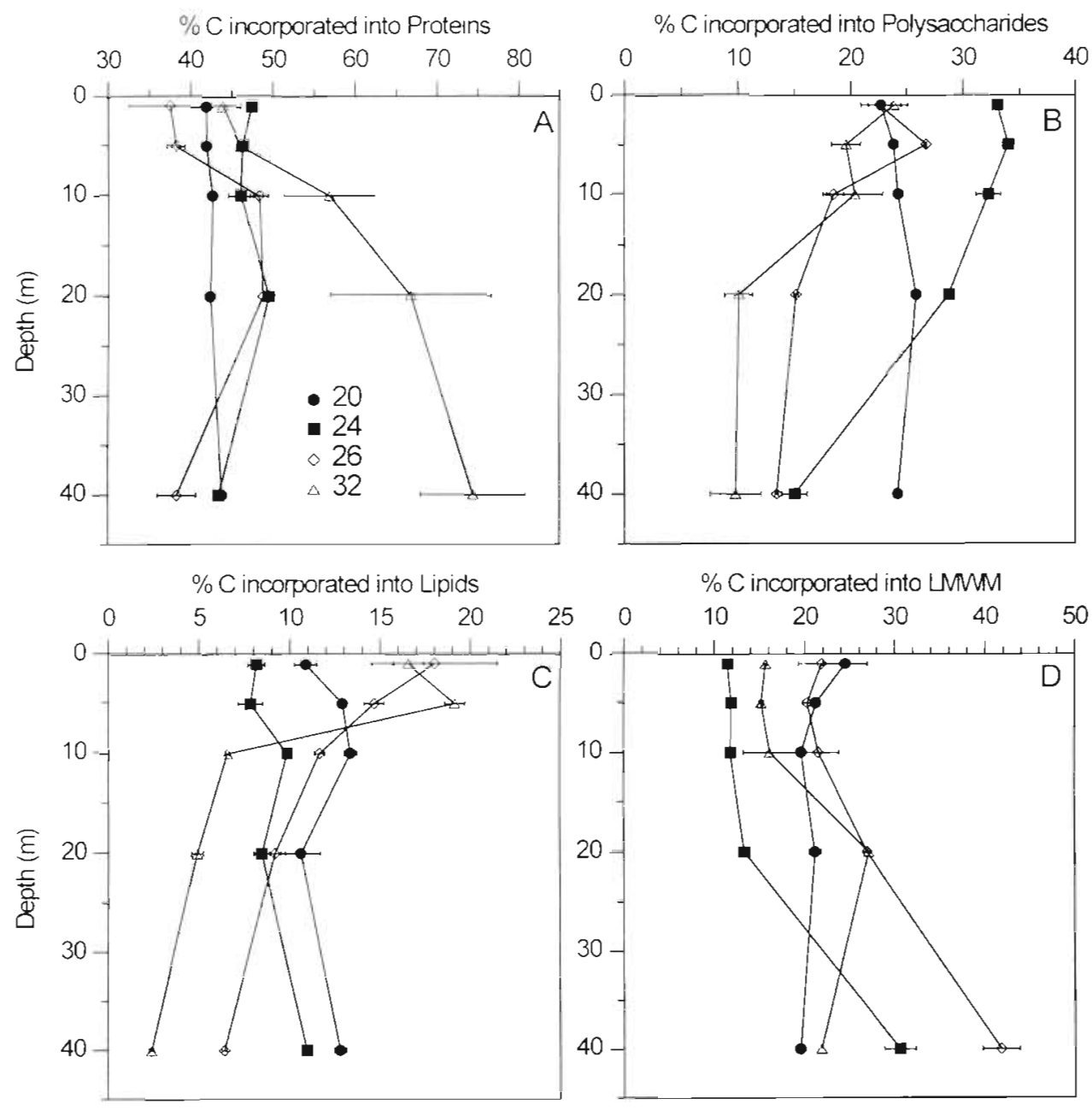

Fig. 7. Vertical profiles of the percentage of $\mathrm{C}$ incorporation into (A) proteins, (B) polysaccharides, (C) lipids and (D) low molecular weight metabolites (LMWM) at Stns 20 , 24,26 and 32. Note differences in the $x$-axis scale.

Bars represent $\pm 1 \mathrm{SE}$

synthesis at all the stations sampled during the cruise inside and outside the coccolithophore-rich waters. In the top $10 \mathrm{~m}$, the relative incorporation of carbon into lipids was significantly higher at the stations located in the coccolithophore-rich waters. Average percentage of relative lipid synthesis in the top $10 \mathrm{~m}$ layer at the bloom stations was $16.5 \pm 0.9 \%$, i.e. 1.5 times higher than outside the bloom area $(10.9 \pm 0.7 \%)$. The partitioning of lipid-C into different classes displayed no differences between bloom and nonbloom stations (data not shown). Most of the carbon channeled into the lipid fraction (70 to $90 \%$ ) was incorporated as neutral lipid, whereas glycolipids and phospholipids only accounted for 5 to $15 \%$ of the total lipid synthesis. Increased lipid synthesis in coccolithophore-rich waters resulted in an enhanced lipid content of the particulate organic matter, as shown by the highly significant linear relationship $\left(\mathrm{r}^{2}=0.82\right.$, $\mathrm{p}<0.0001, \mathrm{n}=28$ ) that existed between calcite- $\mathrm{C}$ concentration and the contribution of lipid-C to total POC (Fig. 8B).

\section{Relationships between irradiance and macromolecular synthesis}

Fig. 9 shows the relationships between irradiance and $\mathrm{C}$ incorporation into each biochemical pool for surface phytoplankton assemblages at 2 stations located in the bloom area. Light-saturated rates of total carbon incorporation were $4.46 \mathrm{mg} \mathrm{C} \mathrm{mg} \mathrm{chl} \mathrm{Ch}^{-1} \mathrm{~h}^{-1}$ at Stn 32 and $8.38 \mathrm{mg} \mathrm{C} \mathrm{mg} \mathrm{chl}^{1} \mathrm{~h}^{-1}$ at $\operatorname{Stn} 45$ (Fig. 9A, B) Despite the differences in the actual rates of carbon fixation, the patterns of carbon allocation into different compounds were similar at both stations. Proteins and, to a lesser extent, polysaccharides were the fractions to which more carbon was channeled. The rate of carbon incorporation into proteins increased very quickly at low irradiances and, as a result, maximum rates of protein synthesis were attained at relatively low PAR levels. In contrast, lipid synthesis was slow at low irradiances and continued to increase at higher photon flux densities. These patterns are more easily observed when considering the distribution of the percentage of 


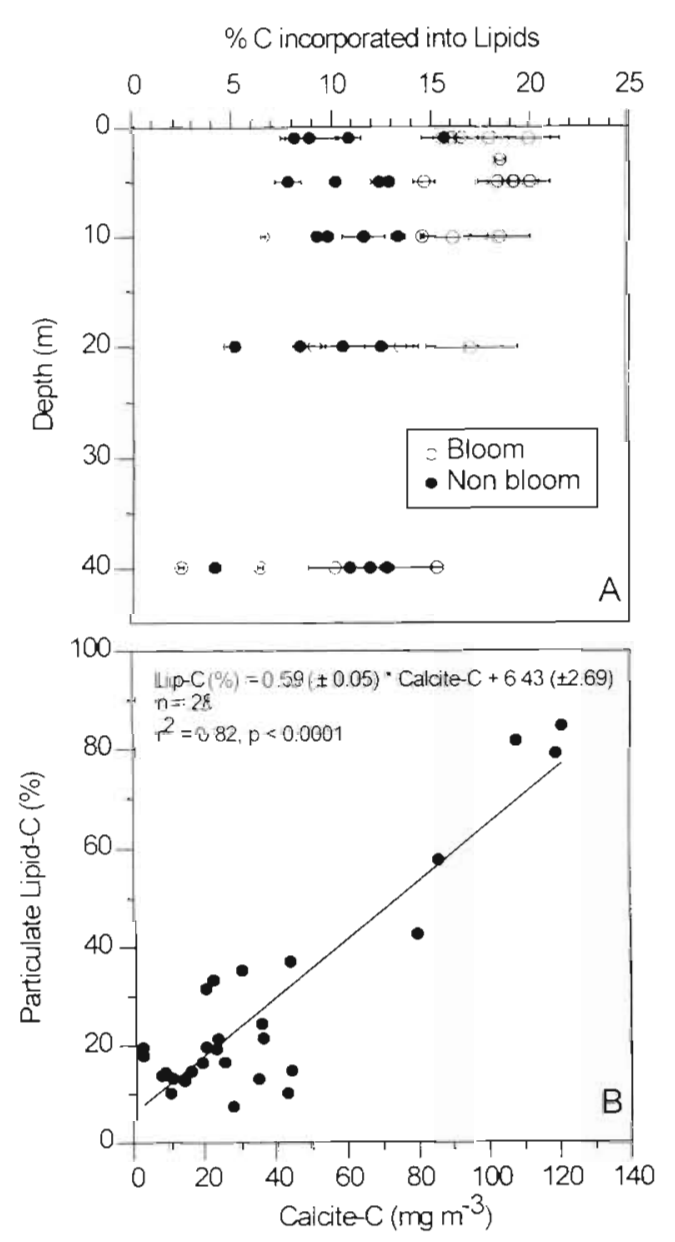

Fig. 8. (A) Relationship between depth and the percentage of photosynthetic $C$ incorporation into lipids at bloom and nonbloom stations. Bars represent \pm 1 SE. (B) Relationship between the relative contribution of lipid-C to total POC and calcite- $C$ concentration

C incorporated into each fraction as a function of irradiance (Fig. 9C, D). The relative synthesis of proteins was highest $(>40 \%)$ at low irradiances, then decreasing at greater light levels. Higher percentages of $\mathrm{C}$ incorporation into LMWM were also found at low irradiances. The relative $\mathrm{C}$ incorporation into polysaccharides and lipids showed the opposite pattern, lowest values being measured at irradiances below $50 \mu \mathrm{E} \mathrm{m}^{-2}$ $\mathrm{s}^{-1}$ Lipid relative synthesis increased steadily with irradiance, reaching maximum percentages (ca 15\%) at $100 \%$ of incident photon flux density.

Light-saturated rates of total carbon incorporation ranged between 3 and $6 \mathrm{mg} \mathrm{C} \mathrm{mg} \mathrm{chl} \mathrm{Ch}^{-1} \mathrm{~h}^{-1}$ in most of the experiments, except at the surface $(3 \mathrm{~m})$ at $\operatorname{Stn} 45$, where a relatively high production was sustained by low chl a levels (Table 3). Proteins and polysaccharides showed the highest values of $P^{\mathrm{B}}$ in all the experiments. Subsurface phytoplankton assemblages at
Stn 45 showed photoinhibition at high irradiances, reflecting photoacclimation of microalgae to low light levels. The photoinhibition parameter $(\beta)$ was very low $\left.1<0.002 \mathrm{mg} \mathrm{C} \mathrm{mg} \mathrm{chl}^{-1} \mathrm{~h}^{-1}\left(\mu \mathrm{E} \mathrm{m} \mathrm{m}^{-2} \mathrm{~s}^{-1}\right)^{-1}\right)$ and was not significantly different from zero in surface assemblages.

Despite their differences in chl a concentration and Emiliania huxleyi density, the phytoplankton assemblages investigated depicted a consistent pattern of relationships between irradiance and carbon partitioning among biomolecules (Table 3). The curves of protein synthesis versus irradiance showed the highest initial slope $(\alpha)$ in all the experiments. On the other hand, lipids exhibited the lowest values of $\alpha$, which for this fraction was always below $0.02 \mathrm{mg} \mathrm{C} \mathrm{mg} \mathrm{chl}^{-1} \mathrm{~h}^{-1}$ $\left(\mu \mathrm{E} \mathrm{m}^{-2} \mathrm{~s}^{-1}\right)^{-1}$. An examination of the values of the light-saturation parameter, $I_{\mathrm{k}}$, reveals that the 4 biochemical pools can be separated into 2 groups according to the irradiance at which their synthesis reaches saturation. Proteins and LMWM showed $I_{k}$ values which were consistently lower than those calculated for total production. In contrast, lipids and polysaccharides displayed a significantly higher value of $I_{k}$ in all the experiments. Overall, $I_{\mathrm{k}}$ values for the lipid fraction exceeded those for proteins by an average factor of 1.8 .

\section{DISCUSSION}

\section{Bloom distribution and development}

The mesoscale distribution of the bloom was restricted to well-stratified waters (Head et al. in press) with enhanced thermal stability (Fig. 2, Table 2) and very low nitrate concentrations $(<0.02 \mu \mathrm{M})$ in the upper mixed layer (Fig. 3, Table 2). This observation agrees with previous studies showing that Emiliania huxleyi blooms tend to occur in highly stratified waters with a shallow (<40 m) upper mixed layer (Balch et al. 1991, Holligan et al. 1993a, Townsend et al. 1994, Van der Wal et al. 1995 among others) where irradiance is high. Lack of photoinhibition would provide competitive advantage to $E$. huxleyi under those conditions (Nanninga \& Tyrrell 1996). However, physical stability and high irradiances alone were not sufficient to explain the 1994 bloom distribution, as $E$. huxleyi did not bloom in the northeastern part of the cruise area where a well-developed thermocline was also present.

In assessing the conditions related to the formation of natural blooms of Emiliania huxleyi, low phosphate has been suggested as a possible causative factor (Townsend et al. 1994). Mesocosm experiments (Egge \& Heimdal 1994), culture competition experiments (Riegman et al. 1992) and modelling studies (Aksnes et 

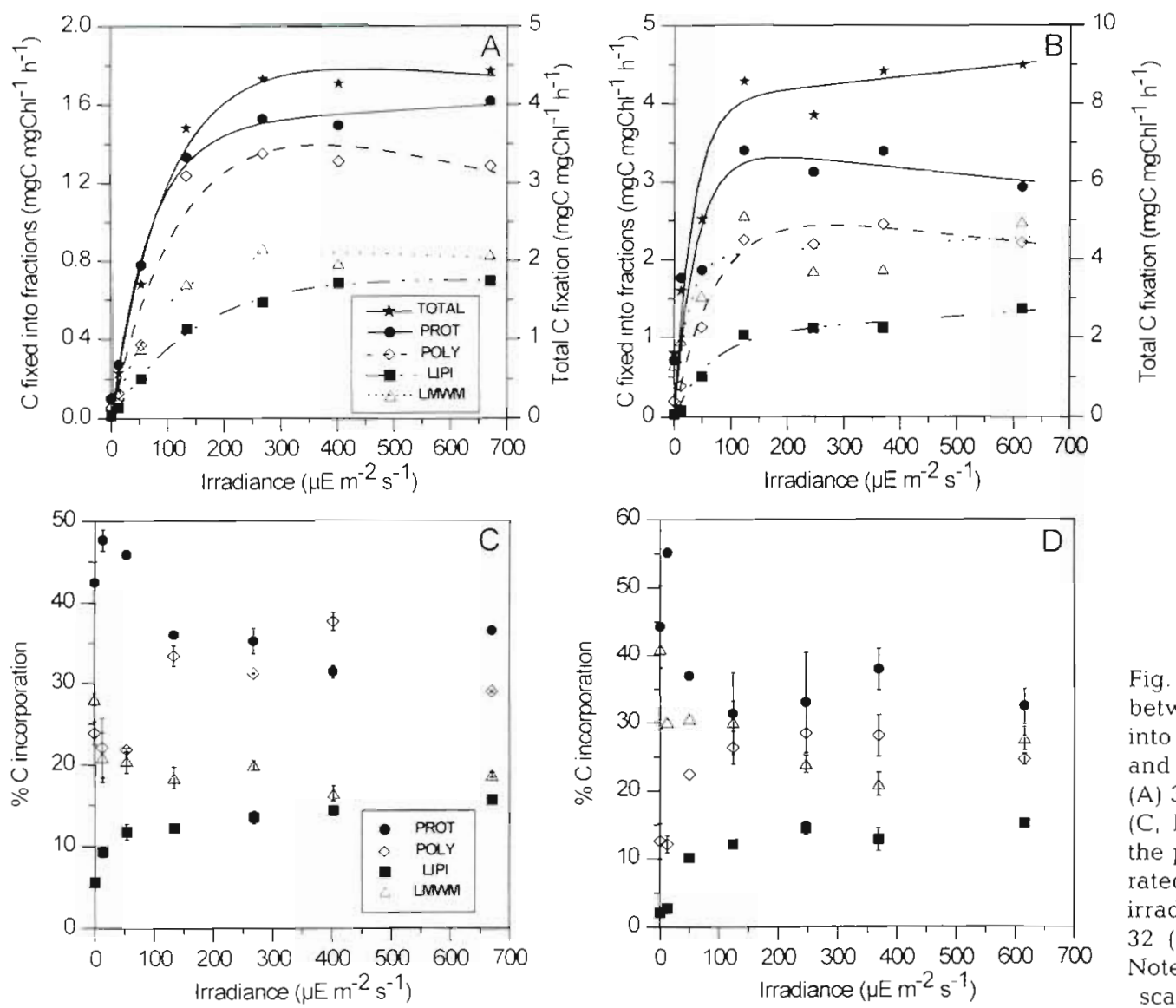

Fig. 9. (A, B) Relationship between the rate of $C$ fixation into each biochemical pool and irradiance at bloom Stns (A) $32(1 \mathrm{~m})$ and (B) $45(3 \mathrm{~m})$. (C, D) Relationship between the percentage of $\mathrm{C}$ incorporated into each fraction and irradiance at bloom Stns (C) $32(1 \mathrm{~m})$ and (D) $45(3 \mathrm{~m})$. Note differences in the $y$-axis scale. Bars represent $\pm 1 \mathrm{SE}$

al. 1994, Tyrrell \& Taylor 1996) have concluded that $E$. huxleyi has a competitive advantage at high $\mathrm{N} / \mathrm{P}$ ratios, which could explain the formation and distribution of these blooms. The results obtained during this study are at odds with this hypothesis. Phosphate concentration showed little variation throughout the cruise, ranging from upper mixed layer average values of 0.3 to $0.7 \mu \mathrm{M}$. E. huxleyi only occurred in high con-

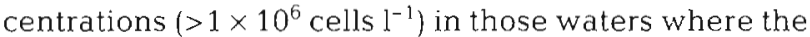
average nitrate concentration in the upper mixed layer was $\leq 1.0 \mu \mathrm{M}$ and the N/P ratio was below 2 . Similarly, Van der Wal et al. (1995) reported lower N/P ratios in coccolithophore-rich waters as compared to the stations outside the bloom. These results suggest that the presence of limiting concentrations of nitrate rather than phosphate is a prerequisite for the development of E. huxleyi blooms in the North Sea.

Despite the observed low concentrations of nitrate in the bloom waters, no clear evidence of nitrogen limitation of phytoplankton growth was detected during this study. $P^{\mathrm{B}}{ }_{\mathrm{m}}$ values (Fig. 9, Table 3) took high values within the bloom area, as compared to those reported in other studies of Emiliania huxleyi blooms (Fernández et al. 1993, Kristiansen et al. 1994). It is well known that small phytoplankton in general (see review by Kiørboe
1993) and E. huxleyi in particular (Eppley et al. 1969) have a high affinity for nitrate and ammonium, which could help explain why the phytoplankton populations in the bloom area were showing high production rates in the absence of measurable nitrate. In addition, the utilization of regenerated nitrogen was more important within the bloom area, as shown by the fact that the f-ratio calculated for coccolithophore-rich waters $(0.2)$ was lower than that measured outside the bloom area (0.5) (Head et al. in press). Similar low f-ratios have been reported for fjord coccolithophore-dominated assemblages (Fernández et al. 1996b). An enhanced role of regenerated nitrogen in sustaining the bloom would be in accordance with recent results showing that ammonium-grown E. huxleyi cultures grow faster than nitrate-grown cultures (Lecourt et al. 1996).

An examination of several biochemical parameters reveals that, unlike previous observations on the biology of coccolithophore blooms, the Emiliania huxleyi bloom studied here was in an early stage of its development. Maximum calcite- $C$ levels measured in the main bloom area during this study $\left(<50 \mathrm{mg} \mathrm{C} \mathrm{m}^{-3}\right)$ were much lower than those reported for blooms in the North Atlantic (300 $\mathrm{mg} \mathrm{C} \mathrm{m}^{-3}$; Holligan et al. 1993a), the North Sea (150 $\mathrm{mg} \mathrm{C}^{-3}$; Van der Wal et al. 1995) 
Table 3. Parameters of the relationship between irradiance and the rate of carbon incorporation into proteins (Prot), polysaccharides (Poly), lipids (Lipi) and low molecular weight metabolites (LMWM) for phytoplankton assemblages in coccolithophore-rich waters of the Hardangerfjorden (Stn 2) and the North Sea (Stns 32 and 45) in June-July 1994. $P^{B}$ : maximum chlorophyll a-

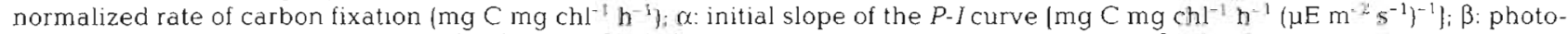

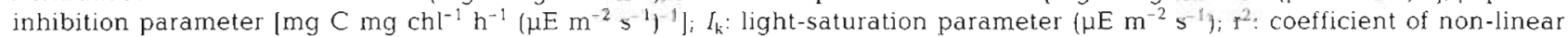
regression; SE: standard error of the estimate. The concentration of chlorophyll a (chl $\left.a_{\text {, }} \mathrm{mg}^{-3}\right)$ and the density of EmilIania huxleyi (Ehux, $10^{6}$ cells $\mathrm{l}^{-1}$ ) are included for reference. See 'Methods' for details

\begin{tabular}{|c|c|c|c|c|c|c|c|c|c|c|c|c|}
\hline Stn & Depth (m) & Chl a & Ehux & Fraction & $P^{B}{ }_{n 1}$ & $\mathrm{SE}$ & $\alpha$ & $\mathrm{SE}$ & $\beta$ & $\mathrm{SE}$ & $I_{\mathrm{k}}$ & $r^{2}$ \\
\hline \multirow[t]{5}{*}{2} & 3 & 3.62 & 9.5 & Total & 3.39 & 0.44 & 0.087 & 0.018 & 0.0019 & 0.0015 & 39 & 0.92 \\
\hline & & & & Prot & 1.04 & 0.14 & 0.032 & 0.006 & 0.0015 & 0.0007 & 32 & 0.91 \\
\hline & & & & Poly & 1.38 & 0.36 & 0.023 & 0.006 & 0.0013 & 0.0014 & 60 & 0.90 \\
\hline & & & & Lipi & 0.63 & 0.11 & 0.014 & 0.003 & 0.0007 & 0.0005 & 45 & 0.91 \\
\hline & & & & LMWM & 0.60 & 0.06 & 0.022 & 0.005 & 0.0003 & 0.0002 & 27 & 0.92 \\
\hline \multirow[t]{5}{*}{32} & 1 & 1.06 & 3.3 & Total & 4.46 & 0.44 & 0.047 & 0.004 & 0.0007 & 0.0009 & 94 & 0.99 \\
\hline & & & & Prot & 1.56 & 0.11 & 0.022 & 0.002 & -0.0001 & 0.0002 & 72 & 0.99 \\
\hline & & & & Poly & 1.40 & 0.43 & 0.013 & 0.002 & 0.0011 & 0.0012 & 106 & 0.96 \\
\hline & & & & Lipi & 0.70 & 0.15 & 0.005 & 0.000 & 0.0001 & 0.0003 & 147 & 0.99 \\
\hline & & & & LMWM & 0.84 & 0.10 & 0.009 & 0.001 & 0.0002 & 0.0002 & 91 & 0.98 \\
\hline \multirow[t]{5}{*}{32} & 20 & 1.23 & 0.9 & Total & 3.15 & 0.62 & 0.046 & 0.008 & 0.0029 & 0.0021 & 68 & 0.89 \\
\hline & & & & Prot & 1.28 & 0.23 & 0.022 & 0.004 & 0.0009 & 0.0007 & 62 & 0.90 \\
\hline & & & & Poly & 0.90 & 0.03 & 0.008 & 0.002 & - & - & 114 & 0.97 \\
\hline & & & & Lipi & 0.34 & 0.16 & 0.004 & 0.000 & 0.0017 & 0.0010 & 94 & 0.98 \\
\hline & & & & LMWM & 0.64 & 0.06 & 0.021 & 0.005 & 0.0002 & 0.0002 & 30 & 0.86 \\
\hline \multirow[t]{5}{*}{45} & 3 & 0.70 & 4.7 & Total & 8.38 & 1.04 & 0.249 & 0.076 & -0.0015 & 0.0022 & 33 & 0.89 \\
\hline & & & & Prot & 3.31 & 0.84 & 0.088 & 0.045 & 0.0009 & 0.0022 & 37 & 0.71 \\
\hline & & & & Poly & 2.44 & 0.29 & 0.036 & 0.005 & 0.0010 & 0.0008 & 67 & 0.98 \\
\hline & & & & Lipi & 1.16 & 0.11 & 0.017 & 0.003 & -0.0004 & 0.0002 & 69 & 0.98 \\
\hline & & & & LMWM & 2.11 & 0.37 & 0.087 & 0.055 & -0.0004 & 0.0009 & 24 & 0.62 \\
\hline \multirow[t]{5}{*}{45} & 20 & 0.92 & 3.7 & Total & 5.99 & 0.91 & 0.175 & 0.028 & 0.0180 & 0.0064 & 34 & 0.92 \\
\hline & & & & Prot & 1.72 & 0.17 & 0.094 & 0.022 & 0.0022 & 0.0008 & 18 & 0.85 \\
\hline & & & & Poly & 1.94 & 0.56 & 0.045 & 0.007 & 0.0107 & 0.0058 & 42 & 0.93 \\
\hline & & & & Lipi & 0.84 & 0.31 & 0.019 & 0.003 & 0.0053 & 0.0036 & 43 & 0.91 \\
\hline & & & & LMWM & 1.44 & 0.21 & 0.048 & 0.009 & 0.0036 & 0.0013 & 30 & 0.91 \\
\hline
\end{tabular}

and the English Channel (250 $\mathrm{mg} \mathrm{C} \mathrm{m}^{-3}$; García-Soto et al. 1995). The contribution of calcite- $C$ to total particulate carbon was also low during this bloom, as the calcite-C to POC ratio was always below 0.25 , compared with 0.5 to 0.6 during the 1993 North Sea bloom (Van der Wal et al. 1995) and $>4$ during a shelf bloom in the English Channel (García-Soto et al. 1995). Similarly, the density of detached liths ( 2 to $3 \times 10^{4} \mathrm{ml}^{-1}$ ) was about 1 order of magnitude lower than typical values for decaying blooms ( 2 to $3 \times 10^{5} \mathrm{ml}^{-1}$ ) (García-Soto et al. 1995, Van der Wal et al. 1995) where the living $E$. huxleyi cell concentration was similar to or even lower than the one measured during this study. The fact that the bloom had not reached its late phase of development allowed us to investigate the patterns of organic and inorganic carbon production when the E. huxleyi populations were still growing actively.

\section{Production of organic and inorganic carbon}

The photosynthesis rates measured in surface, coccolithophore-rich waters during this study were simi- lar to previous estimates for developing blooms with Emiliania huxleyi densities within the same range

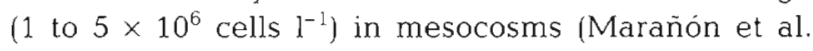
1996), fjords (Kristiansen et al. 1994, Fernández et al. 1996b), the North Atlantic (Fernández et al. 1993) and the North Sea (Van der Wal et al. 1995). In all these cases, the primary production rate was in the range 30 to $70 \mathrm{mg} \mathrm{C} \mathrm{m} \mathrm{m}^{-3} \mathrm{~d}^{-1}$, even though nitrate and phosphate concentrations ranged from $<0.05$ to 12 and $<0.05$ to $4 \mu \mathrm{M}$, respectively. This remarkable constancy in the photosynthesis rate under a wide variety of environmental conditions suggests that primary production during E. huxleyi blooms is constrained by physiological and ecological factors rather than environmental factors such as nutrient or light availability. As reviewed by Furnas (1990), diatoms possess higher growth potential as compared with flagellates when nutrients are available, but their abundance decreases significantly when silicate levels are below $2 \mu \mathrm{M}$ (Egge \& Aksnes 1992). In this connection, Egge \& Jacobsen (1997) have recently shown that silicate additions to experimental enclosures result in the development of diatom blooms with a subsequent 2 - 
fold increase in primary productivity. In addition, grazing control of phytoplankton production is more likely to occur when algal size is small (Kiorboe 1993) and significant grazing by microzooplankton has indeed been reported during E. huxleyi blooms (Holligan et al. 1993a, Nejstgaard et al. 1997). Mesocosm experiments have shown that the succession from a diatom-dominated assemblage to a coccolithophoriddominated assemblage results in a reduction in total productivity accompanied by a shift in the size structure of the community towards a dominance of smaller phytoplankton (Marañon et al. 1996). The results reported in the present study confirm those observations. The ensuing ecological view of an $E$. huxleyi-rich phytoplankton assemblage would be one where small $(<10 \mu \mathrm{m})$ algae are dominant and productivity is low $\left(<1 \mathrm{~g} \mathrm{C} \mathrm{m}^{-2} \mathrm{~d}^{-1}\right)$ and mainly based on regenerated nitrogen.

Maximum absolute calcification rates during this study were 10 to $15 \mathrm{mg} \mathrm{C} \mathrm{m} \mathrm{C}^{-1}$, representing 15 to $20 \%$ of the total carbon incoporation. Cell-normalized calcification rates usually ranged between 1 and 4 pg $\mathrm{C}$ cell-1 $\mathrm{d}^{-1}$ (excluding a value of $13 \mathrm{pg} \mathrm{C}$ cell $^{-1} \mathrm{~d}^{-1}$ at $1 \mathrm{~m}$ on Stn 26), representing an estimated production of 4 to 16 liths cell ${ }^{-1} \mathrm{~d}^{-1}$. These calcification values are lower than previous observations in cultures (Balch et al. 1992) and mesocosms (Van der Wal et al. 1994, Marañón et al. 1996) and comparable with measurements carried out in fjord (Kristiansen et al. 1994, Fernández et al. 1996b) and open sea (Fernández et al. 1993, Van der Wal et al. 1995) blooms. The highest values of the calcification to photosynthesis ratio took place at subsurface depths, in accordance with previous observations of lower saturating irradiances for calcification as compared to those of photosynthesis (Fernández et al. 1993, Van der Wal et al. 1995). Due to the unknown contribution of Emiliania huxleyi photosynthesis to total photosynthesis, the calculated calcification to photosynthesis ratio is likely to misrepresent the actual patterns of carbon allocation by coccolithophores. During the 1991. Iceland bloom, this ratio was never higher than 0.25 in an E. huxleyi population that was growing actively (Fernández et al. 1993). In the present study, where an early stage of the bloom was sampled (see above), this ratio was always lower than 0.4 . By contrast, very high values of the calcification to photosynthesis ratio (ca 1) were measured during this study in the Hardangerfjorden, where a bloom of $E$. huxleyi in a late developmental stage was sampled. These results clearly show that the calcification to photosynthesis ratios in natural $E$. huxleyi populations reflect the contribution of coccolithophores to total phytoplankton biomass and are not valid as indicators of the developmental stage of the bloom.
Extrapolation of results from culture experiments to true conditions at sea is always difficult as a result of the multispecific character of the natural phytoplankton assemblages. This problem becomes particularly relevant in the study of Emiliania huxleyi, because our knowledge of the ecophysiology of this species is largely based on laboratory and mesocosm experiments whereas the contribution of this species to total photosynthetic biomass during open ocean blooms is usually low (Balch et al. 1992. Fernández et al. 1993, Van der Wal et al. 1995). A different situation is found in mesocosms (Van der Wal et al. 1994) and fjord (Fer. nández et al. 1996b) blooms, where E. huxleyi biomass may account for up to $70 \%$ of total photosynthetic biomass. During the 1994 bloom, E. huxleyi biomass always represented less than $30 \%$ of total POC and 40 to $50 \%$ of total chl a was present in the $<5 \mu \mathrm{m}$ size fraction. Taking this as a more realistic scenario for naturally occurring coccolithophore-rich assemblages, it is now possible to assess whether the patterns of photoassimilated $C$ allocation that have been observed in culture and fjord $E$. huxleyi populations are also characteristic of open sea blooms.

\section{Patterns of macromolecular synthesis}

During this study, the photosynthate partitioning was characterized by a high (40 to $50 \%$ ) relative $\mathrm{C}$ flow into the protein fraction (Fig. 7). This feature may reflect the photosynthetic activity of small phytoplankton, given that an increase in the relative synthesis of proteins in the smaller size fractions has recurrently been reported in a number of studies (Howard \& Joint 1989, Jones et al. 1990, Marañón et al. 1996 among others). Proteins are indispensable for the maintenance of basic cellular functions and therefore may constifute non-scalable (sensu Raven 1986) cell components whose relative importance in terms of biomass increases with decreasing size. The highest percentages of $\mathrm{C}$ incorporation into lipids (ca 20\%) were lower than those measured previously in culture and fjord populations (Fernandez et ai. 1994). However, a very strong relationship was found between the presence of Emiliania huxleyi in high concentrations and an increase in the relative lipid synthesis (Fig. 8A). Considering the upper $10 \mathrm{~m}$ of the water column (where the bulk of the E. huxleyi biomass was concentrated), the relative $\mathrm{C}$ incorporation into lipids in coccolithophore-rich waters was $52 \%$ higher than outside the bloom area. In relative terms, this difference in lipid synthesis between E. huxleyj-rich and E. huxleyi-poor assemblages is larger than that found in mesocosms (35\%; Marañon et al. 1996) and equal to the one measured in the fjords ( $52 \%$; Fernández et al. 1996b). The 
storage-related neutral lipids comprised most of the newly synthesized lipid pool, in accordance with previous observations in $E$. huxleyi cultures and natural populations (Fernández et al. 1994). The enhanced synthesis of lipids might provide E. huxleyi populations with a double mechanism to extend their persistence by (1) reducing their sinking rate thanks to a decrease in cellular density (Fernández et al. 1994) and (2) obtaining a storage pool that might be eventually mobilized in order to sustain protein synthesis when environmental conditions become limiting for growth (see below).

The enhanced lipid synthesis found in coccolithophore-rich waters brought about an enrichment in the lipid content of the particulate matter. These results represent a confirmation with open sea populations of previous observations in mesocosms and fjord studies where higher particulate lipid-C concentrations have been measured in association with the occurrence of Emiliania huxleyi blooms (Fernández et al. 1994). The increase in the relative abundance of particulate lipids was correlated to calcite concentration (Fig. 8B) rather than E. huxleyi density. This may reflect the time lag existing between the physiological processes involved in $C$ partitioning among different compounds and the accumulation of lipid through the food web. The strong, positive correlation between calcite- $C$ concentration and relative lipid abundance indicates that lipids are not used as a short-term storage pool but conserved over longer time scales, therefore embodying further ecological significance. It is well known that prymnesiophytes in general (Sargent et al. 1987) and E. huxleyi in particular (Pond \& Harris 1996) contain large amounts of certain polyunsaturated fatty acios that are essential for the development and survival of crustacean and fish larvae (Sargent et al. 1989. Bell \& Sargent 1996). Transfer of lipid through the pelagic food web may be accomplished through zooplankton grazing on E. huxleyi and favoured by the fact that these blooms occur at a time when larval stages of zooplankton are most abundant (Williams \& Lindley 1980). The potential impact of E. huxleyi blooms on the trophic dynamics of the pelagic ecosystem remains to be established and will ultimately depend upon the transfer efficiency of phytoplankton biomass to higher food chain levels.

Although the literature on the $P$-I characteristics of Emiliania huxleyi populations is abundant (see review by Nanninga \& Tyrrell 1996), no information was available on the patterns of $\mathrm{C}$ allocation into different biochemical pools as a function of irradiance. Our results clearly show that in $E$. huxleyi-rich assemblages highest relative $\mathrm{C}$ incorporation into proteins occur at low irradiances, whereas the synthesis of lipids increases at high photon flux densities (Fig. 9, Table 3). The inverse relationship between protein relative synthesis and irradiance has been described before for cultured (Chan 1978, Rivkin 1989) and natural (Cuhel et al. 1984, Hawes 1990) phytoplankton, although without explicitly calculating any functional parameters for the $P$-I curves. The original view by Morris (1980) that the synthesis of proteins tends to be conserved under unfavourable conditions has recently been confirmed for diatom-dominated assemblages under light limitation (Marañón et al. 1995) and flagellate-dominated assemblages under nutrient limitation (Marañón \& Fernández 1995). The implication is that the synthesis of storage compounds is more dependent on light and nutrient availability. In this connection, Fernández et al. (1996a) have suggested that E. huxleyi cells would incorporate a higher fraction of $\mathrm{C}$ into lipids during the early stages of bloom development, when irradiance is high and energy is in excess. When the cells sink out of the euphotic layer and become light limited, they might allocate more $\mathrm{C}$ into the synthesis of proteins in order to sustain cellular division. The relationships reported here between irradiance and the synthesis of proteins and lipids in natural E. huxleyi-rich assemblages support this hypothesis. Furthermore, the same basic patterns of light-dependent $\mathrm{C}$ allocation were found in microalgal assemblages comprising diatoms, flagellates and coccolithophores where the E. huxleyi abundance varied widely. We conclude that the maintenance of protein synthesis under low irradiance conditions and the enhancement of lipid synthesis when an excess of energy is available represent a general strategy of energy utilization by marine phytoplankton.

Acknowledgements. We are deeply indebted to Emilio Fernández for his encouragement and constructive criticism throughout our work. We also thank principal scientist Jorun Egge (University of Bergen) for her support during the cruise and for providing data on phytoplankton taxonomy. Thanks are given to Anita Jacobsen and Hildegunn Bernsten (University of Bergen) for providing chlorophyll $a$ and nutrient concentrations, respectively; Bob Head and David Lesley (Plymouth Marine Laboratory) for POC and calcite-C data; David Crawford (University of Southampton) for total $\mathrm{CO}_{2}$ data; Sven Ove Linde and Runar Dalløkken (Trondheim Biological Station) for irradiance profiles; Evy Skjoldal (University of Bergen) for size-fractionated chlorophyll a data; and Derek Harbour (PML) for information on the phytoplankton species composition. We are grateful to Toby Tyrrell (University of Southampton) and Ricardo Anadón (University of Oviedo) for discussion and useful suggestions. Comments by W. J. Henley and 2 anonymous reviewers improved an earlier version of the manuscript. E.M. acknowledges the receipt of a TMR fellowship from the European Union. This work was funded by the Norwegian Research Council and the European Union under contract MAS-CT92-0038. This is EHUX contribution No. 65. 


\section{LITERATURE CITED}

Aksnes DL, Egge JK, Rosland R, Heimdal BR (1994) Representation of Emiliania huxleyi in phytoplankton simulations models: a first approach. Sarsia 79:291-300

Balch WM, Fritz J, Fernández E (1996) Decoupling of calcification and photosynthesis in the coccolithophore Emiliania huxleyi under steady-state light-limited growth. Mar Ecol Prog Ser 142:87-97

Balch WM, Holligan PM, Ackleson SG, Voss KJ (1991) Biological and optical properties of mesoscale coccolithophore blooms in the Gulf of Maine. Limnol Oceanogr 36: $629-643$

Balch WM, Holligan PM, Kilpatrick KA (1992) Calcification, photosynthesis and growth of the bloom forming coccolithophore, Emiliania huxleyi. Cont Shelf Res 12 $1353-1374$

Barnes H, Blackstock J (1973) Estimation of lipids in marine animal and tissues; detailed investigation of the sulphophosphovanillin method for 'total' lipids. $J$ Exp Mar Biol Ecol 12:103-118

Bell MV, Sargent JR (1996) Lipid nutrition and fish recruitment. Mar Ecol Prog Ser 134:315-316

Brown CW, Yoder JA (1994) Coccolithophorid blooms in the global ocean. J Geophys Res 99(C):7467-7482

Buitenhuis E, Van Bleijswijk JDL, Bakker D, Veldhuis $M$ (1996) Trends in inorganic and organic carbon in a bloom of Emiliania huxleyi in the North Sea. Mar Ecol Prog Ser 143:271-282

Chan AT (1978) Comparative physiological study of marine diatoms and dinoflagellates in relation to irradiance and cell size. I. Growth under continuous light. J Phycol 14: $396-402$

Cuhel RL, Ortner PB, Lean DRS (1984) Night synthesis of protein by algae. Limnol Oceanogr 31:1364-1373

Egge JK, Aksnes DL (1992) Silicate as regulating nutrient in phytoplankton competition. Mar Ecol Prog Ser 83:281-289

Egge JK, Heimdal BR (1994) Blooms of phytoplankton including Emiliania huxleyi (Haptophyta). Effects of nutrient supply in different N:P ratios. Sarsia 79:333-348

Egge JK, Jacobsen A (1997) Influence of silicate on particulate carbon production in phytoplankton. Mar Ecol Prog Ser 147:219-230

Eppley RW, Rogers JN, McCarthy JJ (1969) Half-saturation constants for uptake of nitrate and ammonium by marine phytoplankton. Limnol Oceanogr 14:912-920

Fernández E, Balch WM, Maranón E, Holligan PM (1994) High rates of lipid biosynthesis in cultured, mesocosm and coastal populations of the coccolithophore Emiliania huxleyi. Mar Ecol Prog Ser 114:13-22

Fernández E, Boyd P. Holligan PM, Harbour DS (1993) Production of organic and inorganic carbon within a large scale coccolithophore bloom in the North Atlantic Ocean. Mar Ecol Prog Ser 97:271-285

Fernández E, Fritz JJ, Balch WM (1996a) Chemical composition of the coccolithophorid Emiliania huxleyi under steady state growth. J Exp Mar Biol Ecol 207:149-160

Fernández E, Marañón E, Harbour DS, Kristiansen S, Heimdal BR (1996b) Patterns of carbon and nitrogen uptake during blooms of Emiliania huxleyi in two Norwegian fjords. J Plankton Res 18:2349-2366

Fraga F, Pérez FF (1990) Transformaciones entre composición química del fitoplancton, composición elemental y relación de Redfield. Scientia Mar 54:69-76

Furnas MJ (1990) In situ growth rates of marine phytoplankton: approaches to measurement, community and species growth rates. J Plankton Res 12:1117-1151
García-Soto C, Fernández E, Pingree RD. Harbour DS (1995) Evolution and structure of a shelf coccolithophore bloom in the western English Channel. J Plankton Res 17: $2011-2036$

Grasshoff K, Ehrhardt M, Kremling M (1983) Methods of seawater analysis, 2 nd edn. Verlag Chemie, Weinheim

Hama TN, Handa N, Takahashi F, Whitney F, Wong CS (1988) Change in distribution patterns of photosynthetically incorporated $\mathrm{C}$ during phytoplankton bloom in controlled experimental ecosystem. J Exp Mar Biol Ecol 120: $39-56$

Hawes I (1990) The effects of light and temperature on photosynthate partitioning in Antarctic freshwater phytoplankton. J Plankton Res 12:513-518

Head RN, Crawford D, Egge JK, Lesley D, Kristiansen D, Marañon E, Pond D, Purdie D, Harris RP (in press) The hydrography and biology of a bloom of the coccolithophorid Emiliania huxleyi in the northern North Sea. J Sea Res

Holligan PM, Aarup T, Groom SB (1989) The North Sea: satellite colour atlas. Cont Shelf Res 9:667-765

Holligan PM, Fernández E, Aiken J, Balch WM, Boyd $P$, Burkill PH, Finch M, Groom SB, Malin G, Muller K, Purdie DA, Robinson C. Trees C, Turner SM, Van der Wal PA (1993a) A biogeochemical study of the coccolithophore Emiliania huxleyi in the North Atlantic. Global Biogeochem Cycles 7:879-900

Holligan PM, Groom SB, Harbour DS (1993b) What controls the distribution of the coccolithophorid Emiliania huxleyi in the North Sea? Fish Oceanogr 2:175-183

Holligan PM, Harris RP, Newell RC, Harbour DS, Linley EAS, Lucas MI, Tranter PRG, Weekley CM (1984) Vertical distribution and partitioning of organic carbon in mixed, frontal and stratified waters of the English Channel. Mar Ecol Prog Ser 14:111-127

Holligan PM, Viollier M, Harbour DS, Camus P, ChampagnePhillippe M (1983) Satellite and ship studies of coccolithophore production along a continental shelf edge. Nature 304:339-342

Howard KM, Joint IR (1989) Physiological ecology of picoplankton in the North Sea. Mar Biol 102:275-281

Jones TW, Malone TC, Pike S (1990) Seasonal contrasts in diurnal carbon incorporation by phytoplankton size classes of the coastal plume of Chesapeake Bay. Mar Ecol Prog Ser 68:129-136

Kiørboe T (1993) Turbulence, phytoplankton cell size, and the structure of pelagic food webs. Adv Mar Biol 29:1-72

Kristiansen S, Thingstad TF, Van der Wal P, Fabrot T, Skjoldal EF (1994) An Emiliania huxleyi dominated subsurface bloom in Samnangerfjorden, Western Norway. Importance of hydrography and nutrients. Sarsia 79:357-368

Lecourt M, Muggli DL, Harrison PJ (1996) Comparison of growth and sinking rates of non-coccolith-forming and coccolith-forming strains of Emiliania huxleyi (Prymnesiophyceae) grown under different irradiances and nitrogensources. J Phycol 32:371-381

Li WKW, Harrison WG (1982) Carbon flow into the end-products of photosynthesis in short and long incubations of a natural phytoplankton population. Mar Biol 72:175-182

Marañón E, Fernández E (1995) Changes in phytoplankton ecophysiology across a coastal upwelling front. J Plankton Res 17:1999-2008

Marañón. E, Fernández E, Anadón R (1995) Patterns of macromolecular synthesis by natural phytoplankton assemblages under changing upwelling regimes: in situ observations and microcosms experiments. J Exp Mar Biol Ecol $188: 1-28$ 
Marañón E, Fernández E, Harris RP, Harbour DS (1996) Effects of the diatom-Emiliania huxleyi succession on photosynthesis, calcification and carbon metabolism by size-fractionated phytoplankton. Hydrobiologia 317 . $189-199$

Matrai PA, Keller MD (1993) Dimethylsulfide in a large-scale coccolithophore bloom in the Gulf of Maine. Cont Shelf Res 13:831-843

Morris I (1980) Paths of carbon assimilation. In: Falkowski PG (ed) Primary productivity in the sea. Plenum Press, New York, p 139-159

Nanninga HJ, Tyrrell T (1996) Importance of light for the formation of algal blooms of Emiliania huxleyi. Mar Ecol Prog Ser 136:195-203

Nejstgaard JC, Gismervik I, Solberg PT (1997) Feeding and reproduction by Calanus finmarchicus, and microzooplankton grazing during mesocosm blooms of diatoms and the coccolithophore Emiliania huxleyi. Mar Ecol Prog Ser 147:197-217

Paasche E, Brubak S (1994) Enhanced calcification in the coccolithophorid Emiliania huxleyi (Haptophyceae) under phosphorus limitation. Phycologia 33:324-330

Paasche E, Brubak S, Skattebøl S, Young JR, Green JC (1996) Growth and calcification in the coccolithophorid Emiliania huxleyi (Haptophyceae) at low salinities. Phycologia 35: $394-403$

Platt T, Gallegos CL, Harrison WG (1980) Photoinhibition of photosynthesis in natural assemblages of marine phytoplankton. J Mar Res 38:687-701

Pond DW, Harns RP (1996) The lipid composition of the coccolithophore Emiliania huxleyi and its possible ecophysiological significance. J Mar Biol Assoc UK 76: $579-594$

Raven JA (1986) Physiological consequences of extremely small size for autotrophic organisms in the sea. In: Platt $T_{\text {, }}$ Li KW (eds) Photosynthetic picoplankton. Can Bull Fish Aquat Sci 214

Riegman R, Noordeloos AAM, Cadée GC (1992) Phaeocystis blooms and eutrophication of the continental coastal zones of the North Sea. Mar Biol 112:479-484

Rivkin RB (1989) Influence of irradiance and spectral quality on the carbon metabolism of phytoplankton. I. Photosynthesis, chemical composition and growth. Mar Ecol Prog Ser 55:291-304

Rivkin RB, Voytek MA (1987) Photoadaptation of photosynthesis and carbon metabolism by phytoplankton from McMurdo Sound, Antarctica. I. Species-specific and com-

Editorial responsibility: Otto Kinne,

Oldendorf/Luhe, Germany munity respones to reduced irradiances. Limnol Oceanogr 32:249-259

Robertson JE, Robinson C, Turner DR, Holligan PM, Watson A, Boyd P, Fernández E, Finch M (1994) The impact of a coccolithophore bloom on oceanic carbon uptake in the N. E. Atlantic during summer 1991. Deep Sea Res 41: $297-314$

Sargent JR, Henderson RJ, Tocher DR (1989) The lipids. In Halver JE (ed) Fish nutrition, 2nd edn. Academic Press, San Diego, p 152-218

Sargent JR, Parkes RJ, Mueller-Harvey I, Henderson RJ (1987) Lipid biomarkers in marine ecology. In: Sleigh MA (ed) Microbes in the sea. Ellis Horwood Ltd, Chichester, p $119-138$

Smith AE, Morris I (1980) Pathways of carbon assimilation in phytoplankton from the Antarctic Ocean. Limnol Oceanogr 25:865-872

Smith REH, D'Souza FML (1993) Macromolecular labelling patterns and inorganic nutrient limitation of a North Atlantic spring bloom. Mar Ecol Prog Ser 92:111-118

Townsend DW, Keller MD, Holligan PM, Ackleson SG, Balch WM (1994) Blooms of the coccolithophore Emiliania huxleyi with respect to hydrography in the Gulf of Maine. Cont Shelf Res 14:979-1000

Tyrrell T, Taylor AH (1996) A modelling study of Emiliania huxleyi in the NE Atlantic. J Mar Syst 9:83-112

Van der Wal P, Kempers RS, Veldhuis MJW (1995) Production and downward flux of organic matter and calcite in a North Sea bloom of the coccolithophore Emiliania huxleyi. Mar Ecol Prog Ser 126:247-265

Van der Wal P, Van Bleijswijk JDL, Egge JK (1994) Primary productivity and calcification rate in blooms of the coccolithophorid Emiliania huxleyi (Lohmann) Hay et Mohler developing in mesocosms. Sarsia 79:401-408

Volkman JK, Eglinton G, Corner EDS, Forsberg TEV (1980) Long-chain alkenes and alkenones in the marine coccolithophorid Emiliania huxleyi. Phytochem 19:2619-2622

Westbroek P, Brown CW, Van Bleijswijk J, Brownlee C. Brummer JG, Conte M, Egge JK, Fernández E, Jordan R, Knappertbuch M, Stefels J, Veldhuis MJW, Van der Wal P, Young J (1993) A model system approach to biological climate forcing. The example of Emiliania huxleyi. Global Planet Change 8:27-46

Williams R, Linley JA (1980) Plankton of the Fladen Ground during FLEX 76 III. Vertical distribution, population dynamics and production of Calanus finmarchicus (Crustacea: Copepoda). Mar Biol 60:47-56

Submitted: May 5, 1997; Accepted: August 7, 1997

Proofs received from author(s): September 15, 1997 